\title{
Handhaving door Nederlands privaatrecht
}

\author{
Jeroen Kortmann en Carla Sieburgh
}

\section{Inleiding}

Handhaving door privaatrecht staat in het Nederlandse juridische debat in het middelpunt van de belangstelling. Een belangrijke aanleiding hiervoor is gelegen in het Europeesrechtelijke vereiste van effectiviteit van het Europese recht ${ }^{\mathrm{I}}$ en de in het verlengde daarvan liggende handhaving van rechtsregels door het privaatrecht. Concrete voorbeelden hiervan zijn de handhaving van het verbod op discriminatie, de handhaving van het mededingingsrecht ${ }^{2}$ en de handhaving van consumentenrechten. Uit de rechtspraak van het Europese Hof van Justitie geven wij de volgende beeldende passages:

Met betrekking tot de gelijke behandeling van mannen en vrouwen, op grond van richtlijn 76/207 EEG:3

\footnotetext{
' 23 Ook al is ... voor een volledige tenuitvoerlegging van de richtlijn niet een bepaalde sanctie op schending van het discriminatieverbod noodzakelijk, voorwaarde is wel dat de sanctie een daadwerkelijke en doeltreffende rechtsbescherming kan verzekeren. Verder dient zij ten aanzien van de werkgever een echt afschrikkende werking te hebben. (...).' (curs. JK en $\mathrm{CS})^{4}$
}

En uit Courage/Crehan, over het recht van particulieren om schadevergoeding te vorderen wegens de schending van art. 8I EG:5

I. Zie over het Europeesrechtelijke effectiviteitsbeginsel en het privaatrecht Asser/Hartkamp $3-I^{\star}$ (2008), nr. 87 e.v.

2. Zie daarover A.M.A.P. van den Bossche, 'De privaatrechtelijke handhaving van Europese mededingingsregels', in: A.S. Hartkamp. C.H. Sieburgh \& L.A.D. Keus (red.), De invloed van het Europese recht op het Nederlandse privaatrecht, Deventer 2007, p. 2II e.v.; M.R. Mok, 'Regels betreffende de mededinging', in: A.S. Hartkamp. C.H. Sieburgh \& L.A.D. Keus (red.), De invloed van het Europese recht op het Nederlandse privaatrecht, Deventer 2007, p. 578 en J.S. Kortmann \& C.R.A. Swaak, 'The EC White paper on antitrust damage actions: why the member states are (right to be) less than enthusiastic', ECLR 2009, 340-35I.

3. Inmiddels is bij richtlijn 2002/73 in deze richtlijn de verplichting tot het betalen van een reële en effectieve schadevergoeding opgenomen.

4. HvJ EG Io april I984, I4/83 (Von Colson en Kamann/Land Nordrhein-Westfalen), Jurispr. I984, p. I89I.

5. HvJ EG 20 september 200I, C-453/99 (Courage/Crehan), Jurispr. 200I, p. I-6297, NJ 2002, 43. 
' 27 Een dergelijk recht maakt de communautaire mededingingsregels immers gemakkelijker toepasbaar, waardoor - vaak verborgen - overeenkomsten of praktijken die de mededinging kunnen beperken of vervalsen, minder aantrekkelijk worden. In zoverre kunnen bij de nationale rechter ingediende schadevorderingen wezenlijk bijdragen tot de handhaving van een daadwerkelijke mededinging in de Gemeenschap.' (curs. JK en CS).

Naast de invloed van het Europese recht speelt ook een rol dat in het Nederlandse juridische debat de instrumentele benadering van het privaatrecht aan kracht wint, daarbij niet zelden gevoed door theorieën die afkomstig zijn uit de Verenigde Staten en door gegevens ontleend aan de rechtseconomie en de rechtspsychologie. ${ }^{6}$

Zo pleitte Van Nispen al in 1987 voor het ontwikkelen van de instrumentele functie van het privaatrecht met een sanctiearsenaal dat een door hem gesignaleerd 'rechtshandhavingstekort'7 zou kunnen ondervangen. In zijn proefschrift uit $200 \mathrm{I}$ over aanpassingen van de bewijslastverdeling in het aansprakelijkheidsrecht, koos Giesen als leidraad 'de verwezenlijking van de materiële norm'. Hij pleitte ervoor de bewijslastverdeling zodanig aan te passen dat de materiele norm handhaafbaar is. ${ }^{8}$ Een jaar later betoogde Verheij dat bij vergoeding van immateriële schade de handhavingsfunctie een belangrijke rol speelt:

'De rechtshandhavingsfunctie in de hier bedoelde zin houdt in dat het privaatrecht in staat dient te zijn om te reageren op de inbreuk op een privaatrechtelijk recht. Deze reactie dient niet te geschieden met het oog op (speciale of generale) preventie, maar is een kwestie van logische noodzaak: zonder (re)actie geen recht.' 9

Van Boom bracht vervolgens in zijn Rotterdamse oratie de handhavende functie van het contractenrecht en het onrechtmatige daadsrecht nog uitdrukkelijker onder de aandacht van het privaatrechtelijke discours. De kenmerken van de meeste bestaande rechtsmiddelen (de vernietiging van de overeenkomst, het terugtreden van de overeenkomst, schadevergoeding wegens wanprestatie en schadevergoeding

6. In I984 nam S. Shavell, 'Liability for Harm versus Regulation of Safety', Journal of Legal Studies (I984), p. 517 e.v. de stelling in dat handhaving door de overheid moet plaatsvinden en niet door rechtelijke procedures tussen individuen onderling. Daarop is gereageerd door C. Kolstad e.a., 'Ex Post Liability for Harm vs. Ex Ante Safety Regulation: Substitutes or Complements?', Am. Ec. Rev. I990, p. 888 e.v. Zie daarover F. Cafaggi \& H.W. Micklitz, 'Collective Enforcement of Consumer Law: A Framework for Comparative Assessment', ERPL 2008, p. 394-395. Zij zien in de ontwikkeling van de mogelijkheid van 'collective enforcement' reden voor interactie tussen handhaving door de overheid en privaatrechtelijke handhaving in een juridische procedure.

7. C.J.J.C. van Nispen, Sancties in het vermogensrecht, Mon. NBW A-11, I druk, Deventer I987 nr. 4 en $2^{\mathrm{e}}$ druk, Deventer 2003, nr. 3. Wij wijzen erop dat het postuleren van een 'handhavingstekort' is ingegeven door doelen die Van Nispen aan het privaatrecht stelt maar die niet noodzakelijkerwijze als doelen van het privaatrecht gelden. Indien aspecten als 'bestraffing van de aansprakelijke persoon' en 'genoegdoening van de benadeelde' niet zonder meer als doel van het privaatrecht worden aanvaard, zal het door Van Nispen gesignaleerde handhavings'tekort' minder frequent optreden resp. niet als een tekort worden aangemerkt.

8. I. Giesen, Bewijs en aansprakelijkheid, Den Haag 2001.

9. A.J. Verheij, Vergoeding van immateriële schade wegens aantasting in de persoon, Nijmegen 2002, p. 445 . 
wegens onrechtmatige daden en in geval van risicoaansprakelijkheid) zijn volgens Van Boom dat zij te zeer zijn gericht op herstel en specifiek zijn toegesneden op het concrete geval. Hij ziet deze kenmerken als 'a major impediment to efficacious enforcement of private law'. Teneinde (potentiële) daders te ontmoedigen zich onrechtmatig te gedragen, pleit Van Boom onder meer voor de invoering van punitive damages, die hij voor de gelegenheid omdoopt tot post-facto ${ }^{\mathrm{IO}}$ incentive damages. Een dergelijke op specifieke afschrikking gerichte schadevergoeding zou wel passen in de Europese rechtscultuur, mits daarbij aan bepaalde voorwaarden wordt voldaan. ${ }^{\text {II }}$ Verder was de vruchtbare interactie tussen privaatrechtelijke handhaving en ingrijpen van de overheid op het gebied van het consumentenrecht onderwerp van een door Van Boom met Loos geredigeerde bundel met internationale bijdragen. ${ }^{12}$ Tegelijkertijd met het werk aan dit preadvies wordt onder redactie van Engelhard e.a. een bundel over handhaving van en door het privaatrecht voorbereid.

In het schadevergoedingsrecht heeft de oproep van Van Boom weerklank gekregen. Zo overweegt Hartlief dat privaatrechtelijke handhaving een 'welkome aanvulling' kan zijn op handhaving door de overheid. ${ }^{13}$ Hij blijft voorzichtig:

'Of we aldus werkelijk een betere samenleving creëren, is nog maar de vraag. (...) We zullen echter ook oog moeten hebben voor de gevaren van juridisering en een claimcultuur (rem op innovatie, defensive medicine en dergelijke). En wat dacht u van burgers die zich overal en nergens verantwoordelijk voor gaan voelen en zich dus overal mee gaan bemoeien en activistische rechters die uit een zelfde soort hout gesneden zijn en misschien wel beter dan wetgever en politiek menen te weten hoe onze samenleving eruit zou moeten zijn? Een wenkend perspectief?'I4

\section{Uitgesproken tegengeluiden zijn er ook, zij het mondjesmaat. ${ }^{15}$}

Het tijdsgewricht waarin het debat over de handhaving van het privaatrecht zich afspeelt kenmerkt zich hierdoor dat de grenzen tussen publiekrecht (staatsrecht, strafrecht en administratief recht) en privaatrecht minder scherp worden. Zo staat het privaatrecht onder de invloed van constitutionele normen. Het dient plaats in te ruimen voor publiekrechtelijke regels die horizontale directe werking hebben (zoals

Io Grammaticaal juist zou zijn te spreken van 'post-factum incentive damages'.

II. W.H. van Boom, Efficacious Enforcement in Contract and Tort, Den Haag 2006.

I2. W.H. van Boom \& M. Loos (ed.), Collective Enforcement of Consumer Law: Securing Compliance in Europe through Private Group Action and Public Authority Intervention, Groningen 2007.

I3. T. Hartlief, 'Handhaving met smartengeld', AV\&-S 2008, p. 238, 246-247.

I4. T. Hartlief, 'Handhaving in het aansprakelijkheidsrecht. Op weg naar een betere samenleving?', WPNR 6772 (2008), p. 777. In T. Hartlief, 'Wat staat het burgerlijk recht te doen?', NJB 2009, p. I553, onderkent Hartlief de beperkte mogelijkheden die het privaatrecht heeft en betoogt hij dat het burgerlijke recht moet samenwerken met het publieke recht om belangrijke normen van een publiekrechtelijke erkenning en sanctionering te voorzien.

15. J.S. Kortmann, The Tort Law Industry, Amsterdam 2009, tevens te verschijnen in ERPL 2009/5, W.P.J. Wils, 'The Relationship between Public Antitrust Enforcement and Private Actions for Damages', World Competition 32 (2009), p. 3 e.v. 
een aantal bepalingen uit het EG Verdrag). Daarnaast verwierven het strafrecht en het bestuursrecht de mogelijkheid een civielrechtelijke schadevergoeding toe te kennen.

Als wij schrijven dat de grenzen tussen privaatrecht en publiekrecht minder scherp worden, veronderstelt dit dat die grenzen scherp zijn geweest. Het is de vraag of dat echt zo is. Na de geboorte van het publieke recht uit het civiele recht zijn er steeds actuele onderwerpen geweest die zich op het grensvlak van beide gebieden hebben afgespeeld. Waar de grenzen overigens scherp leken, bleken zij dat met betrekking tot zo'n actueel onderwerp niet te zijn. Het is denkbaar dat een grens zich scherper voordoet dan zij is, als zich op dat deel van de grens geen actuele problemen afspelen. Zodra een probleem actueel wordt, komt de ware aard van de juridische grens, haar onscherpte, naar boven.

\section{Rechtshandhaving door privaatrecht}

\section{I.I Handhaven en sanctie}

Het woord handhaven is volgens Van Dale's Groot woordenboek der Nederlandse taal en Ethymologisch woordenboek tussen I30I en I400 ontstaan, in de betekenis van 'de hand slaan aan'. Het is gerelateerd aan het Middelhoogduitse handhaben (vastpakken, beschermen) dat ontstond onder invloed van het Latijnse manu tenere (met de hand vasthouden) en het Franse maintenir. Dat laatste woord ligt ten grondslag aan de wapenspreuk van het huis Oranje-Nassau, 'Je maintiendrai', die in I8I5 de wapenspreuk werd van het Verenigd Koninkrijk der Nederlanden. Na de afscheiding in I830 behield Nederland deze wapenspreuk. De tegenwoordige, voor ons onderwerp relevante betekenis is 'in stand houden, ervoor waken dat iemand of iets blijft in de staat of toestand waarin hij (het) zich bevindt, zorgen dat iets niet geschonden wordt'.

In het debat over handhaving door privaatrecht, zoals dit thans wordt gevoerd, wordt echter niet uitgegaan van een eenduidig begrip handhaving. Stelt een eigenaar bijvoorbeeld de revindicatie in tegen een bezitter, dan wordt wel gezegd dat hij daarmee zijn recht op eigendom 'handhaaft'. Aldus krijgt het begrip handhaving de zeer ruime betekenis van 'het doen gelden van een recht'. ${ }^{16}$ Hanteert men het begrip in deze ruime zin, dan geeft de stelling dat het privaatrecht mede dient tot handhaving van rechten niet een aan het privaatrecht eigen perspectief. Gaat men daarentegen uit van een enger begrip handhaving - in de hiervoor genoemde zin van het 'in stand houden, ervoor waken dat iemand of iets blijft in de staat of toestand waarin hij (het) zich bevindt, zorgen dat iets niet geschonden wordt' - dan vormt de revindicatie niet de handhaving van het eigendomsrecht. De revindicatie voorkomt immers niet dat het eigendomsrecht geschonden wordt. Meer precies strekt de revindicatie ertoe

I6. In deze ruime zin gebruikt S.D. Lindenbergh, Schadevergoeding: algemeen. Deel 1. Mon. BW B34, Deventer 2008, nrs. 4 en 5 het begrip handhaving. 
de eigenaar de exclusieve macht over zijn zaak terug te geven. Zij heeft derhalve een herstellende functie. De rechtsregels die ertoe strekken te voorkomen dat het eigendomsrecht geschonden wordt - de eigendom te 'handhaven' in de hiervoor bedoelde engere zin van dat woord - zijn in de eerste plaats in ons Wetboek van Strafrecht te vinden (bijvoorbeeld de strafbepalingen over diefstal en verduistering).

In het debat over handhaving wordt verder dikwijls gesproken van 'sanctionering'. Ook dat is geen eenduidig begrip. Volgens Van Dale is het woord afgeleid van het Latijnse sanctio ((straf)bepaling, verordening), dat als oorsprong heeft sancire (vastleggen, bekrachtigen, verordenen (op straffe van)) dat verwant is met het Latijnse woord sacer (heilig). In het hedendaagse taalgebruik heeft het twee zeer uiteenlopende betekenissen, namelijk 'bekrachtiging, erkenning of goedkeuring door een daartoe bevoegd gezag van een bestaande toestand of van een genomen besluit of maatregel' en 'middel om de naleving van een voorschrift of verdragsbepaling af te dwingen of als straf voor een overtreding, dwangmiddel'. Evident is dat in het handhavingsdebat het begrip sanctie in de tweede betekenis - die van 'straf' of 'dwangmiddel' - wordt gebruikt. Maar daarmee is niet gezegd dat een ieder die het begrip hanteert, uitgaat van dezelfde betekenis.

In Nederland is de sanctie als privaatrechtelijk verschijnsel reeds in 1978 door Van Nispen onder de aandacht gebracht. ${ }^{17}$ Hij verstaat onder sanctie 'de van rechtswege intredende gevolgen van en door het recht toegelaten reacties op gepleegd onrechtmatig gedrag alsmede door het recht toegelaten maatregelen ter voorkoming van dreigend onrechtmatig gedrag'. ${ }^{18} \mathrm{Hij}$ merkt dus zowel 'reacties op overtreding van een verplichting' als de 'maatregelen van preventie ingeval overtreding dreigt' aan als een sanctie. ${ }^{19}$ Zo begrepen zijn 'sancties' ruim gezaaid in ons privaatrecht.

Anderen hanteren het begrip sanctie echter in de meer beperkte zin van straf of dwangmiddel om de naleving van (rechts)normen af te dwingen. Interessant is bijvoorbeeld wat Hart hierover bij zijn behandeling van 'nullity as a sanction' opmerkt:

'No one could deny that there are, in some cases, the associations between nullity and such psychological factors as disappointment of the hope that a transaction will be valid. Nonetheless the extension of the idea of a sanction to include nullity is a source (and a sign) of confusion.'

Het belangrijkste argument van Hart om een nietigheid of vernietigbaarheid niet als een sanctie te zien, is dat zij niet vergelijkbaar zijn met een bestraffing als aansporing

I7. De handhavende functie van het privaatrecht als tegenstelling van de compensatoire functie van het privaatrecht of als daarmee samenlopend werd onderwerp van internationaal debat sinds de publicatie van Shavell e.a., Journal of Legal Studies (I984), a.w., p. 517 e.v. (die de nadruk legde op de tegenstelling) en de reactie daarop van Kolstad e.a., Am. Ec. Rev. (I990), a.w., p. 888 e.v. (die aandacht vroegen voor de samenloop van beide functies).

I8. C.J.J.C. van Nispen, Het rechterlijk verbod en bevel, Deventer 1978, p. I6-I7.

I9. Van Nispen, Mon. NBW A-11, $2^{\mathrm{e}}$ druk, a.w., nr. I. 
om af te zien van de schending van bepaalde normen of regels. De rechtsfiguren van de nietigheid of vernietigbaarheid dienen er niet toe het sluiten van overeenkomsten te ontmoedigen. $\mathrm{Zij}$ onthouden slechts juridische erkenning aan deze gedragingen. ${ }^{20}$ Dat het recht bepaalde overeenkomsten als nietig of vernietigbaar aanmerkt, kan dan ook niet voorkomen dat burgers feitelijk dergelijke overeenkomsten aangaan, om vervolgens op basis van vertrouwen onderling af te rekenen.

Wat er zij van het betoog van Hart, het maakt duidelijk dat wat door Nederlandse en Nederlandstalige juristen in het dagelijkse taalgebruik gemakkelijk als sanctie wordt beschouwd, ${ }^{2 \mathrm{I}}$ uitgaat van een zeer ruime betekenis van het woord sanctie. Voor het debat over handhaving door privaatrecht is het niet noodzakelijk om privaatrechtelijke rechtsmiddelen als ontbinding, nietigheid en vernietigbaarheid en schadevergoeding uit te sluiten van het begrip 'sanctie'. Zeker niet nu het ruime begrip sanctie reeds lang geleden zijn intrede heeft gedaan in het burgerlijke recht.

Wel van belang is steeds duidelijk in het oog te houden of sprake is van een sanctie die dient als aansporing om af te zien van schending van bepaalde normen of regels. Is daarvan sprake, dan heeft de privaatrechtelijke sanctie een handhavende functie in de door ons hiervoor beschreven zin. Daarvoor is overigens niet noodzakelijk dat de sanctie ook een leedtoevoegend karakter heeft, zoals veel strafrechtelijke sancties hebben. ${ }^{22}$ De aansporing om af te zien van de schending van een norm of regel kan ook daarin bestaan dat, in plaats van de 'schender' leed toe te voegen, hem een door de schending gerealiseerd voordeel wordt ontnomen. Anders gezegd: een sanctie heeft een handhavende functie als zij strekt tot de ontmoediging een norm te schenden door hetzij potentiële schenders een nadeel in het vooruitzicht te stellen, hetzij hun voor te houden dat het voordeel dat zij met de normschending nastreven zal worden weggenomen.

\section{I.2 Verhouding publiekrecht - privaatrecht}

Voor het sinds 1992 in Nederland geldende Burgerlijk Wetboek is gekozen om regels van staats- en administratief recht daar zoveel mogelijk buiten te houden:

20. H.L.A. Hart, The Concept of Law, Oxford ig6r, p. 33-34.

2I. Zo stelt W. Van Gerven, Beginselen van Belgisch Privaatrecht, Algemeen Deel, $2^{\mathrm{e}}$ druk, Antwerpen I973, p. 399: 'Nietigheid is een sanctie gesteld op het niet-naleven door de rechtsgenoten bij het verrichten van een rechtshandeling, van door de rechtsorde belangrijk geachte rechtsregels. Zij is niet de enige mogelijke sanctie: schadevergoeding, niet-tegenstelbaarheid van de verrichte rechtshandeling, ontbinden van de rechtshandeling en vermindering der aangegane verbintenis zijn andere civielrechtelijke sancties (...). Nietigheid is wel de meest ingrijpende en derhalve meteen de beste en de slechtste sanctie: de beste, omdat zij zoveel mogelijk de vroegere toestand herstelt; de slechtste omdat zij een ernstige storing betekent van het rechtsverkeer.'

22. G.J.M. Corstens, Het Nederlands strafprocesrecht, $6^{\mathrm{e}}$ druk, Deventer 2008, p. 2. Corstens beschouwt de straf als een leedtoevoegende sanctie. 'Het bijzondere karakter ervan is dat zij niet gericht is op herstel van onrecht. Met de oplegging van straf wordt de burger terecht gewezen en wordt hem leed toegevoegd en dit laatste wordt ook beoogd.' Zie ook G.J.M. Corstens, 'Civielrechtelijke, administratiefrechtelijke of strafrechtelijke rechtshandhaving', Pre-advies NJV I984 in: Handelingen der Nederlandse Juristen-Vereniging 1984, deel I, eerste stuk, Zwolle I984, p. 2I e.v. 
'Het criterium dat ter onderscheiding van administratief recht en privaatrecht is gekozen, is of de handhaving van de norm in handen van belanghebbenden zelf of van de overheid is gelegd en met name of de handhaving geschiedt met rechtsmiddelen die voor het privaatrecht typerend zijn: civiele acties tot nakoming, tot schadevergoeding, ofwel tot ontbinding of vernietiging van rechtsverhoudingen of verklaring van recht.' 23

Over het werkelijke onderscheid tussen privaat- en publiekrecht zegt dit weinig. Immers, het wezen van een rechtsnorm kan niet worden gedefinieerd door te verwijzen naar het rechtsmiddel dat de wetgever ter handhaving van die norm creëert ${ }^{24}$ of naar de plaats in de codificatie waar de wetgever dat rechtsmiddel onderbrengt.

In een poging om de tegenstelling tussen het wezen van publiekrechtelijke normen en privaatrechtelijke normen te duiden, schreef Meijers:

'Publiekrechtelijke normen hebben in de eerste plaats het algemeen belang op het oog; zij staan onder contrôle van overheidsorganen, die tegen overtreding met strafvervolgingen of politiedwang optreden.' 25

Volgens Opzoomer bestaat 'tusschen beide een zeer scherpe tegenstelling':

'In het publieke recht is het geheel, in het privaatrecht het individu als doel te beschouwen. ${ }^{26}$

Omdat publiekrechtelijke normen zich primair richten op het algemene belang, is het uitgangspunt dat de staat belast is met hun handhaving. Dit uit zich onder meer in het monopolie van de overheid op de vervolging en bestraffing van burgers. De burger heeft in ons recht in beginsel geen rol bij de bestraffing van normovertredend handelen. Immers, '(het monopolie der staatsvervolging) sluit particulieren, zelfs benadeelden en belanghebbenden, van rechtstreekse deelneming aan de vervolging uit'. ${ }^{27}$

23. A.S. Hartkamp, Aard en opzet van het nieuwe vermogensrecht, Mon. NBW A1, $3^{\mathrm{e}}$ druk, Deventer 2002, p. 29, onder verwijzing naar de in noot 25 te noemen passage in de Toelichting Ontwerp Meijers.

24. Zie ook Het Burgerlijk wetboek verklaard door C.W. Opzoomer, deel I, $3^{\mathrm{e}}$ druk, 's-Gravenhage IgII, p. 7 , voetnoot $\mathrm{I}$.

25. Toelichting Ontwerp Meijers, Algemene Inleiding, te kennen uit Ontwerp voor een Nieuw Burgerlijk Wetboek, Toelichting, Eerste gedeelte (Boek 1-4), Den Haag 1954, p. I2, waar op p. I3 wordt uiteengezet dat de scheidslijn niet altijd scherp valt te trekken.

26. Het Burgerlijk wetboek verklaard door C.W. Opzoomer, deel I, 3 e druk, a.w., p. 7.

27. Parlementaire geschiedenis bij het Wetboek van Strafvordering, Bijl. Hand. II I9I7/I9I8, 77 stuk I, p. 44-45, Stb. I92I, I4. Vgl. ook B. Windscheid, Lehrbuch des Pandektenrechts, Vol. II, $9^{\mathrm{e}}$ druk, Frankfurt am Main I9o6, p. 354, voetnoot 6 ('Es darf als durchgreifender Grundsatz des heutigen Rechts bezeichnet werden, daß der Staat in der Geltendmachung eines öffentlichen Interesses, und so namentlich auch in der Einforderung der Strafe, nicht durch jeden, der daß will, vertreten werden kann'). 
Het Nederlandse privaatrecht richt zich op de betrekkingen tussen individuen. Privaatrechtelijke beginselen als restitutio in intergrum, het verrijkingsbeginsel en de redelijkheid en billijkheid beogen in de eerste plaats gerechtigheid tussen de individuele partijen te bevorderen.

In theorie kan een 'zeer scherpe tegenstelling' bestaan tussen publiekrechtelijke en privaatrechtelijke normen, in de praktijk is dit onderscheid niet altijd eenvoudig te herkennen. Voor wie goed zoekt, zijn ook in ons Nederlands Burgerlijk Wetboek rechtsregels te vinden die niet alleen - en soms zelfs niet primair - dienen ter bescherming van een privaat belang (het 'individu'). Zij strekken er veeleer toe de schending van een publiek belang (het 'geheel') te ontmoedigen. In dit preadvies staat die handhavende functie van het privaatrecht centraal. Wij zullen ons derhalve primair richten op de privaatrechtelijke handhaving van normen die het individuele belang van de private partijen overstijgen. Om die reden wordt bijvoorbeeld het boetebeding niet behandeld. ${ }^{28}$

\section{I.3 Afbakening en vraagstelling}

Benadrukt zij dat er, net als tussen doel en gevolg, een belangrijk verschil is tussen de 'handhavende functie' van het privaatrecht en de 'handhavende werking' van het privaatrecht. Terwijl juist is dat van ons schadevergoedingsrecht een zekere afschrikwekkende werking uitgaat - hetgeen kan bijdragen aan de naleving van gedragsnormen en dus wenselijk is - is twijfelachtig of normhandhaving een zelfstandig doel is van ons schadevergoedingsrecht. Wie stelt dat een goede werking van ons schadevergoedingsrecht een positieve bijdrage kan leveren aan de handhaving van de normen, zegt daarmee dus niets controversieels. De meer ter zake doende vraag is in hoeverre ons privaatrecht (mede) dient of zou moeten dienen ter handhaving van die normen. Zou het antwoord bevestigend luiden, dan is de vervolgvraag welk instrumentarium het privaatrecht aan de burger verschaft, waarbij ook van belang is of dit voldoende is om dit doel te verwezenlijken. Deze vragen staan centraal in dit pre-advies.

Wij gaan daarbij als volgt te werk. In hoofdstuk 2 onderzoeken wij in hoeverre belangrijke deelgebieden van het geldende privaatrecht mede dienen ter handhaving van normen die verder strekken dan ter bescherming van individuele partijbelangen. Bij de keuze voor deelgebieden beoogden wij een 'dwarsdoorsnede' van het vermogensrecht te geven: het aansprakelijkheidsrecht, het overeenkomstenrecht, het intellectuele eigendomsrecht, het goederen- en faillissementsrecht en geen verbodsacties. Om te kunnen vaststellen in hoeverre deze deelgebieden van het geldende vermogensrecht een handhavende functie hebben, zullen wij nagaan op welke punten zij regels kennen die als doel hebben de burger aan te sporen af te zien van normschendend gedrag. In hoofdstuk 3 evalueren wij onze bevindingen. In dat verband zullen wij aangeven in hoeverre het privaatrecht naar onze opvatting zou

28. Zie daarover H.N. Schelhaas, Het boetebeding in het Europese contractenrecht, Deventer 2004. 
moeten dienen ter handhaving. Ten aanzien van de door ons besproken onderdelen van het vermogensrecht zullen wij aangeven in welke gevallen een handhavend rechtsmiddel onzes inziens ten onrechte bestaat en in welke gevallen onzes inziens een ruimer gebruik gemaakt kan worden van een rechtsmiddel met een handhavende werking. Hieruit destilleren wij vier grote lijnen die in hoofdstuk 4 worden uitgezet: geen private straffen, een ruimer gebruik van winstafdracht en afgifte van voordeel in gevallen van ontbreken van goede trouw, een meer flexibele inzet van nietigheid en ongedaanmaking en vraagtekens bij de wijze waarop de dwangsom in het geldende systeem is ingericht.

Consequentie van de door ons gekozen afbakening en vraagstelling is dat wij bepaalde ook aan 'private handhaving' rakende onderwerpen in dit preadvies onbesproken zullen laten. Zo zullen wij bijvoorbeeld niet ingaan op de mogelijkheid om een 'blote' verklaring voor recht te vragen dat bepaald gedrag onrechtmatig was. ${ }^{29}$ Wij onderkennen dat een verklaring voor recht in zekere mate kan bijdragen aan de handhaving van normen die het privaatrecht overstijgen. Immers, het feit dat een rechter een norm vaststelt of de grenzen van een norm nader bepaalt, kan ertoe leiden dat die norm in de toekomst beter wordt nageleefd. Dat makkt echter niet dat handhaving het doel is van een dergelijke verklaring voor recht. Als en voor zover een 'blote' verklaring voor recht naar Nederlands recht gevorderd kan worden, strekt zij er primair toe het slachtoffer van onrechtmatig gedrag genoegdoening te geven..$^{\circ}$ Genoegdoening is een van handhaving te onderscheiden functie en valt daarmee buiten het bereik van dit preadvies.

\section{Handhaving in het Nederlandse privaatrecht}

\section{I Onrechtmatige daad}

De rechthandhavingsgedachte duikt in allerlei gedaanten op in het debat over het aansprakelijkheidsrecht. Velen zien handhaving niet zozeer als een doel van het

29. Uit onder meer HR 5 juni 2009, RvdW 2009, 685; JOR 2009, 200, m.nt. C.W.M. Lieverse, JA 2009, II8 m.nt. W.H. van Boom (Stichting Gedupeerden Spaarconstructie/Aegon Bank) wordt door enkelen afgeleid dat het Nederlandse recht de enkele verklaring voor recht dat het gedrag van gedaagde onrechtmatig was, als zelfstandige sanctie erkent. Zie bijvoorbeeld de annotatie van Van Boom onder dat arrest van in JA 2009, II8.

30. Zie C.E. du Perron, 'Genoegdoening in het civiele aansprakelijkheidsrecht', Preadvies NJV 2003 in: Handelingen der Nederlandse Juristen-Vereniging 2003, Deventer 2003, in het bijzonder p. I53 e.v. Zie over genoegdoening verder A.J. Akkermans, E.M. Uijttenbroek, K.A.P.C. van Wees \& J.E. Hulst, 'Excuses in het privaatrecht', WPNR 6772 (2008), p. 778 e.v. en R.M.E. Huver, K.A.P.C. van Wees, A.J. Akkermans \& N.A. Elbers, Slachtoffers en aansprakelijkheid. Een onderzoek naar behoeften, verwachtingen en ervaringen van slachtoffers en hun naasten met betrekking tot het civiele aansprakelijkheidsrecht, Deel I, WODC 2007, raadpleegbaar op www.wodc.nl/images/I345_volledige_tekst_tcm4479806.pdf en A.J. Akkermans, J.E. Hulst, E.A.M Claassen, A. ten Boom, N.A. Elbers, K.A.P.C. van Wees, D.J.Bruinvels, Slachtoffers en aansprakelijkheid. Een onderzoek naar behoeften, verwachtingen en ervaringen van slachtoffers en hun naasten met betrekking tot het civiele aansprakelijkheidsrecht, Deel II, WODC 2008, raadpleegbaar op www.eerstekamer.nl/behandeling/20090209/rapport_slachtoffers_en/f=/vi2gn4s49chI.pdf. 
aansprakelijkheidsrecht, maar als een wenselijk neveneffect. Bloembergen zag in I982 het vergoeden van schade als een bijdrage tot 'de - overigens onvolmaakte handhaving van rechten'. De centrale doelstelling van het schadevergoedingsrecht is compensatie. ${ }^{3 \mathrm{I}}$ Ook Lindenbergh nam in 1998 in zijn dissertatie over smartengeld (art. 6:Io6 BW) de stelling in dat bij de toekenning van smartengeld de compensatoire functie daarvan centraal staat. De preventieve functie betreft naar huidig schadevergoedingsrecht 'een effect van het opleggen van een sanctie die wordt vormgegeven aan de hand van de compensatiefunctie.' Het vormgeven van een schadevergoedingsrechtelijke sanctie met het oog op preventie ('punitive damages') heeft niet zijn voorkeur. Een uitzondering acht hij denkbaar voor grove schendingen van persoonlijkheidsrechten uit een oogpunt van winstbejag. ${ }^{32}$ Van Boom meent dat het stimuleren van individuele schadevergoedingsacties (zoals door de Europese Commissie wordt bepleit ten aanzien van de handhaving van mededingingsrecht) niet de juiste wijze is om te ontmoedigen. Om leemtes in de administratiefrechtelijke handhaving te vullen, wil hij de door hem tot 'post-facto incentive damages' omgedoopte, in Europa nauwelijks aanvaarde 'punitive damages', inzetten in gevallen van een schending van duidelijk vervatte (wettelijke) plichten en van herhaald schenden van het oordeel van de burgerlijke rechter.33

Het bestaan van de wettelijke plicht om schade te vergoeden aan de benadeelde kan als neveneffect een handhavende werking hebben. Het vooruitzicht op het nadeel een schadevergoeding te moeten betalen, kan de potentiële normschender ontmoedigen zich onrechtmatig te gedragen. Voor zover dat neveneffect optreedt, is dat vanzelfsprekend wenselijk. Ontmoediging van normschendingen is echter geen zelfstandig doel van het aansprakelijkheidsrecht. Het aansprakelijkheidsrecht richt zich niet primair op de normschender, maar op de gelaedeerde. De vergoedingsplicht is dan ook niet verbonden aan de normschending als zodanig, maar ontstaat pas als schade daadwerkelijk is veroorzaakt. Het is afhankelijk van toevallige omstandigheden óf schade zal ontstaan en welke de omvang daarvan is. Zo kan het gebeuren dat een ernstige normschending zonder gevolg blijft en een betrekkelijk onschuldige normschending resulteert in een omvangrijke schadevergoedingsplicht. 'Als straf is de schadevergoeding dan ook ten enenmale ongeschikt', aldus Bloembergen. 34

Ten aanzien van twee specifieke deelonderwerpen wordt evenwel de gedachte dat het geldende aansprakelijkheidsrecht een handhavende functie heeft, breder gedragen. Het betreft de figuur van de 'winstafdracht' en de aansprakelijkheid voor

3I. A.R. Bloembergen, Schadevergoeding: algemeen, deel 1, Mon. NBW B34, Deventer 1982, p. 2-7. Als nevenfuncties noemt hij genoegdoening voor de benadeelde, ongedaanmaking van een verrijking van de aansprakelijke persoon, herstel van de oude toestand, handhaving van rechten, straf voor de (schuldige) aansprakelijke persoon en preventie van schade.

32. S.D. Lindenbergh, Smartengeld, Deventer I998, p. 6I, 62, 348 en Mon. BW B34, a.w., p. I5-I6.

33. Van Boom, Efficacious Enforcement in Contract and Tort, a.w., p. 35 e.v.

34. Bloembergen, Mon. NBW B34, a.w. p. 7 . 
inbreuk op persoonlijkheidsrechten en immateriële belangen en de figuur van de 'winstafdracht'.

\subsubsection{Persoonlijkheidsrechten en immateriële belangen}

Artikel 6:Io6 lid I BW bepaalt dat in bepaalde omstandigheden ook nadeel dat niet in vermogensschade bestaat, recht op schadevergoeding kan geven. Het betreft onder meer gevallen waarin de benadeelde lichamelijk letsel heeft opgelopen, in zijn eer of goede naam is geschaad of op andere wijze in zijn persoon is aangetast.

Ook auteurs zoals Hartlief die de uiterste terughoudendheid betrachten ten aanzien van een handhavend privaatrecht, zien in geval van de schending van een persoonlijkheidsrecht iets in de mogelijkheid van 'punitive damages' of 'incentive damages'. 35 Een dankbaar voorbeeld is de boulevardpers, die met een schending van een persoonlijkheidsrecht van een bekende persoon gigantische oplages en winsten kan genereren. Maar ook een persoonlijkheidsrecht van een niet-bekende persoon kan onrechtmatig worden geschonden, bijvoorbeeld zijn privacy, zijn eer en goede naam, zijn recht om niet gediscrimineerd te worden. Van belang is verder dat de rechtspraak onder de aantasting in de persoon van artikel 6:Io6 lid I onder b BW ook de schending van fundamentele rechten verstaat. Niet noodzakelijk is dat de benadeelde een vorm van letsel heeft opgelopen.

De schade die in dergelijke gevallen wordt geleden, is niet gemakkelijk te duiden. Welke schade lijdt iemand die in een sollicitatieprocedure wordt gediscrimineerd wegens geslacht, maar die de baan ook zonder de discriminatie niet zou hebben gekregen, resp. die al een andere baan heeft? En betreft het vermogensschade of 'ander nadeel' (art. 6:95 BW)?36 Naar Nederlands recht is het mogelijk de schending van het persoonlijkheidsrecht zelf als schade aan te merken. De Parlementaire Geschiedenis en de Hoge Raad refereren in dit verband aan 'het geschokte rechtsgevoel' van de benadeelde dat als schade kan worden aangemerkt. Lindenbergh meent, mede onder verwijzing naar Verheij, dat de vergoeding van dergelijke schade

35. Hij verwijst in dit verband naar het werk van Lindenbergh en Verheij. Anders dan Lindenbergh geeft Verheij aan dat de handhavingsfunctie moet worden verwezenlijkt door het privaatrecht bestraffende kenmerken te geven. A.J. Verheij, Vergoeding van immateriële schade wegens aantasting in de persoon, Nijmegen 2002, p. 487 e.v. Verheij geeft de volgende aanknopingspunten om smartengeld ter rechtshandhaving toe te kennen: de aard van het geschonden recht, de mate van aantasting van de zelfbeschikking, de kwetsbaarheid van het geschonden recht, het bestaan van andere handhavingsmiddelen, het voordeel voor de inbreukmaker, de afhankelijkheid van de benadeelde, de kans op de schade en de ernst daarvan en de ongerechtvaardigde verrijking.

36. Vgl. over de praktische gevolgen van schade die 'ander nadeel' is J. van Duijvendijk-Brand, 'Smartengeld in het vermogensrecht: de (vergoeding voor) smart of het (kwalificeren als) geld, wat geeft de doorslag?', AV\&S 2008, p. 264 e.v. 
niet een compensatoire functie heeft, maar een handhavende functie. Hetgeen daarop langs de glijdende schaal weer zou volgen zijn 'punitive damages'. ${ }^{37}$

Het is echter de vraag, of in geval van inbreuk op persoonlijkheidsrechten ons aansprakelijkheidsrecht werkelijk een andere - handhavende - functie heeft. Artikel 6:Io6 lid I BW spreekt 'gewoon' van schadevergoeding. Zo ook Van Duijvendijk (ten aanzien van een bepaald soort immateriële schade):

\begin{abstract}
'Smartengeld beoogt een financiële tegemoetkoming te bieden voor pijn, verdriet en gederfde levensvreugde. Het gaat daarbij niet om het vergoeden van schade die de persoon in zijn vermogen lijdt, maar om het bieden van compensatie voor schade toegebracht aan diens welzijn. De compensatie is echter noodzakelijkerwijs (...) in geld.' (curs. JK en CS) ${ }^{38}$
\end{abstract}

Onzes inziens is dit juist. Vergoeding van immateriële schade waarvan de vermogensrechtelijke omvang niet (goed) vaststelbaar is, kan toch compensatoir zijn. Zo kan de veroorzaking van naar omvang niet goed vaststelbare schade als gevolg van de schending van een persoonlijkheidsrecht door discriminatie gevolgd worden door een vergoeding die compensatoir van aard is. Dat schade niet of niet precies berekend kan worden, leidt niet dwingend tot de gevolgtrekking dat geen schade is geleden en dat een vergoeding niet compensatoir van aard zou zijn.

\title{
2.1.2 Winstafdracht
}

Zij die voorstaan dat het aansprakelijkheidsrecht een eigen handhavende functie heeft, wijzen doorgaans ook op de figuur van de winstafdracht (art. 6:104 BW). Zo ziet Van Nispen de figuur van de winstafdracht als een nuttige aanvulling op de 'schadevergoeding als sanctie op toerekenbaar onrechtmatig handelen', die in zijn ogen tekortschiet 'indien het profijt voor de dader groter is dan de voor vergoeding in aanmerking komende schade'.

Wat het algemene Nederlandse aansprakelijkheidsrecht aangaat, bestaat geen recht op winstafdracht die een grotere omvang heeft dan de geleden schade. Door Van Lierop en Pijnacker Hordijk is weliswaar het tegendeel beweerd,39 maar zij zagen HR 24 december 1993, NJ I995, 42I (Waeyen Scheers/Nous) over het hoofd. De Hoge Raad oordeelde dat artikel 6:104 BW aan het slachtoffer van een onrechtmatige daad niet een

37. S.D. Lindenbergh, 'Schending en schade. Over aantasting van fundamentele rechten en eenheid in het schadevergoedingsrecht', in: E.M. Hoogervorst e.a. (red.), Rechtseenheid en vermogensrecht, Deventer 2005, p. 318; Verheij, Vergoeding van immateriële schade wegens aantasting in de persoon, a.w., p. 464 e.v.

38. Van Duijvendijk-Brand, 'Smartengeld in het vermogensrecht', a.w., p. 264.

39. W.A.J. van Lierop \& E.H. Pijnacker Hordijk, Privaatrechtelijke aspecten van het mededingingsrecht Preadvies voor de Vereniging voor Burgerlijk Recht, Deventer 2007, p. 94. 
'vordering tot winstafdracht geeft, maar slechts aan de rechter een discretionaire bevoegdheid verleent om de door het slachtoffer geleden schade te begroten op de door de dader genoten winst. Blijkt dat het slachtoffer geen schade heeft geleden, dan laat het algemene aansprakelijkheidsrecht voor winstafdracht geen ruimte. Het enkele feit dat de dader profijt uit zijn onrechtmatige daad heeft getrokken, maakt hem derhalve niet aansprakelijk'. ${ }^{\circ}$

Kortom: artikel 6:104 BW geeft de rechter weliswaar de discretionaire bevoegdheid de schade te begroten op de genoten winst, maar als blijkt dat de gelaedeerde minder schade heeft geleden dan de onrechtmatig genoten winst, dan moet de rechter de schade begroten op het lagere bedrag. ${ }^{4 \mathrm{I}}$ Dat neemt overigens niet weg dat in de feitenrechtspraak artikel 6:I04 BW toch af en toe gebruikt wordt met het oog op handhaving. Een voorbeeld is Hof Amsterdam, 9 september 2008, NJF 2008/437 (Ymere), waarin het Hof een vordering van een woningbouwcorporatie tegen een huurder die zich schuldig had gemaakt aan illegale onderverhuur, toewees en de schade begrootte op de uit onderverhuur genoten winst. Daarbij hechtte het hof belang aan het feit dat de woningbouwcorporatie beoogde 'een extra en effectief instrument te verkrijgen in de strijd tegen onderverhuur'.

\subsection{Overeenkomstenrecht}

Ook het overeenkomstenrecht kent onderwerpen die naar onze mening niet een 'surplus' aan potentiële handhavende werking hebben ten opzichte van de reeds bestaande handhavende werking, zoals bijvoorbeeld de vernietigbaarheid van overeenkomsten wegens wilsgebreken en de ontbinding van overeenkomsten. Deze leerstukken worden niet besproken. Wij richten ons op de nietigheid (incl. partiele nietigheid en conversie) in samenhang met de ongedaanmaking. Onderdeel van die bespreking maken uit het geldigheidsvereiste voor de borgtocht van artikel 7:858 BW, het nietige proeftijdbeding van artikel 7:652 BW en de loonsverhoging op grond van artikel 7:625 BW. Omdat laatstgenoemd artikel een 'echte' handhavende functie heeft, behandelen wij het als eerste.

\subsubsection{Bestraffende verhoging loon wegens vertraging in betaling}

Wat betreft het door de werkgever aan de werknemer in geld verschuldigde loon regelt artikel 7:625 BW dat de werknemer recht heeft op een verhoging daarvan als dit loon meer dan drie werkdagen later wordt voldaan dan de werkdag waarop voldoening had moeten plaatsvinden. Deze verhoging is een private boete die ertoe strekt de werkgever te prikkelen het in geld verschuldigde loon tijdig te voldoen. Zowel het doel als de werking van het rechtsmiddel is de werkgever te bestraffen. ${ }^{42}$

40. HR 24 december I993, NJ I995, 42I (Waeyen Scheers/Nous).

4I. Evenzo: Ch.R.A. Swaak en M.R. Mok in interventies tijdens de jaarvergadering 2007 van de Vereniging voor Burgerlijk Recht, NTBR 2009/7, p. 269, l.k.

42. Asser/Heerma van Voss $7-\mathrm{V}^{\star} 2008$, nr. IIO-III. 
De verschuldigdheid van de verhoging staat los van door de werknemer (wel of niet) geleden schade. De Hoge Raad heeft dit voor het oude recht (art. I638q Oud BW) aldus geformuleerd:

'(...), dat de in art. I638q geregelde 'verhoging', mede blijkens de wijze waarop deze moet worden berekend, niet zozeer bedoeld is als een vorm van vergoeding van door de werknemer als een gevolg van de vertraagde uitbetaling geleden schade, maar veeleer als een prikkel voor de werkgever om het loon tijdig uit te betalen.' 43

A-G Ten Kate wees er in zijn conclusie voor het arrest op dat de rechter wel de mogelijkheid heeft om de verhoging te matigen op grond van het feit dat de wettelijke rente is gaan lopen. Aan de op zich mogelijke cumulatie van de verhoging met de schadevergoeding in de vorm van wettelijke rente worden aldus grenzen gesteld. Dat neemt niet weg dat artikel 7:625 BW in de kern een 'echte' handhavende functie heeft.

\subsubsection{Nietigheden, (on)mogelijkheid van conversie of partiële nietigheid}

Artikel 3:40 BW regelt de verhouding tussen de rechtshandeling van de autonome burger en de in de maatschappij als geheel geldende minimumbestaansvoorwaarden voor een rechtshandeling. Een rechtshandeling die in strijd is met een dwingende wetsbepaling, de goede zeden en/of de openbare orde is krachtens dat artikel nietig en in sommige gevallen vernietigbaar. Deze regeling heeft een reactieve werking: een rechtshandeling verricht in strijd met de wet is nietig of vernietigbaar. Een rechtshandeling met een inhoud of strekking die in strijd is met de goede zeden of de openbare orde is nietig. Maar aan de regeling kan ook een zekere preventieve werking worden toegekend. Zij ondersteunt in zoverre de handhaving van de normen waarnaar zij verwijst, dat zij voor burgers het juridische nut ontneemt aan het doen van dergelijke rechtshandelingen. Iemand die een rechtshandeling wil verrichten zal de bedoeling hebben een geldige rechtshandeling te verrichten. De dreiging van ongeldigheid brengt mee dat hij zijn rechtshandeling zo zal 'inrichten' dat zij de toetsing aan artikel 3:40 BW zal doorstaan. Een positieve dreiging om zich van handelingen in strijd met wet, goede zeden of openbare orde te onthouden, gaat van deze bepaling echter niet uit.

Bij de preventieve werking van artikle 3:40 BW zijn met reden vraagtekens geplaatst. Degene die een rechtshandeling verricht behoeft zich niet bewust te zijn van de geldende wet. Het wel of niet schenden van zo'n wet kan dan geen rol spelen bij de door hem gekozen inrichting van de rechtshandeling. Aan de andere kant van het spectrum staat degene die zeer goed weet wat wel en niet mag en die desondanks een ongeldige rechtshandeling verricht.

De tendens die ten aanzien van de nietige of vernietigbare rechtshandeling heeft gegolden is de relativering daarvan. Daarmee wordt beoogd aan de ongeldige rechtshandeling zoveel mogelijk werking te geven. Dat wordt bereikt door partiële

43. HR 5 januari 1979, NJ 1979, 207 m.nt. P.A. Stein (Swaen/Van Hees) 
nietigheid, door conversie of bekrachtiging. Wij wijzen in dit verband op het proefschrift van Hijma, die heeft betoogd dat bij rechtshandelingen in strijd met de wet, de goede zeden en/of de openbare orde nietigheid niet altijd op haar plaats is:

'Als de bewuste regel van algemeen belang slechts ten doel had de inmiddels gepleegde daad te voorkomen, is hij door de gebeurtenissen (i.e. het verrichten van de verboden prestatie) achterhaald en daarmee uitgewerkt. Wat resteert is de rechtvaardigheid tussen partijen, die tot het oordeel voert dat nu ook de wederprestatie zal moeten en kunnen plaatsvinden.' 44

Toch kan van nietigheid een zekere preventieve werking uitgaan. Een aardige illustratie vormt de verzekering tegen verkeersboetes die het Zweedse bedrijf Bisso eind 2005 aankondigde op de Nederlandse markt te zullen brengen. Een dergelijke verzekering zou de afschrikkende werking van verkeersboetes ondermijnen. Het voornemen van Bisso leidde tot vragen in de Tweede Kamer, waarop minister Donner geruststellend reageerde met de constatering dat een verzekering tegen verkeersboetes in strijd is met de openbare orde en derhalve nietig. ${ }^{45}$ Nadere wetgeving was niet nodig; een verzekeringsovereenkomst die rechtens niet afdwingbaar is, leidt ertoe dat de verzekering niet wordt verkocht. Aldus ondersteunt het privaatrechtelijke rechtsgevolg, nietigheid, de handhavende werking van het publiekrechtelijke boetesysteem. Een zelfstandige prikkel gaat er evenwel niet van uit. De rechtsregel van artikel 3:40 BW kan bijvoorbeeld niet voorkomen dat burgers feitelijk de risico's van publiekrechtelijke boetes 'poolen', om vervolgens op basis van vertrouwen - derhalve zonder een beroep te doen op de burgerlijke rechter - onderling af te rekenen.

Een andere reden waarom de nietigheid en vernietigbaarheid van artikel 3:40 BW weinig preventieve c.q. handhavende werking hebben is dat naar Nederlands recht de rechtsgevolgen van zo'n nietigheid dikwijls overeenkomen met de rechtsgevolgen die de rechtshandeling zou hebben gehad indien zij geldig was geweest. Het duidelijkst zien we dat bij de wederkerige overeenkomst. Nietigheid van (een van) de rechthandeling(en) ontneemt de grond aan de wederzijds verrichte prestaties. Die prestaties worden op grond van de regeling van de onverschuldigde betaling (art. 6:203 e.v. BW) wederzijds ongedaan gemaakt. Indien een van de prestaties niet ongedaan gemaakt kan worden, behoudt de ontvanger daarvan de prestatie en treedt voor de ongedaanmaking een waardevergoeding in geld in de plaats (art. 6:2Io BW). Die waardevergoeding zal in veel gevallen de omvang van de bedongen betaling benaderen (zie nader hierna, onder 2.2.3 'Restitutierechtelijke gevolgen van nietigheid'). Bij een eenzijdige overeenkomst is dit niet het geval. De prestatie wordt teruggegeven. Met onder andere als gevolg dat zij nogmaals kan worden benut voor hetzelfde, verboden doel.

Tegen deze achtergrond heeft Sieburgh zich uitgesproken tegen de, op de contractsvrijheid teruggaande relativeringstendens op het gebied van de nietigheid en

44. J. Hijma, Nietigheid en vernietigbaarheid van rechtshandelingen, Deventer I988, p. 96.

45. TK 2005-2006, Kamervragen met antwoord, nrs. IIo, 853 en I 396. 
vernietigbaarheid op grond van artikel 3:40 BW. Dit voor gevallen waarin het algemene belang gediend is met een nietigheid of vernietigbaarheid. Om de implicaties voor het algemene belang ten einde te kunnen denken, pleitte zij voor een samenhangende beoordeling van de geldigheid van de overeenkomst en de restitutierechtelijke gevolgen daarvan. Onder omstandigheden zouden overwegingen van preventie kunnen leiden tot het oordeel dat slechts de partij die handelde in strijd met de wet, de goede zeden en/of de openbare orde verplicht is de prestatie ongedaan te maken. Daarmee aanvaardt zij dat de andere partij, zij het niet ongegrond, verrijkt wordt. $4^{6}$

\section{Nietigheid gebruikt om te handhaven: concrete voorbeelden}

Hoewel in de regel naar partiële nietigheid, conversie of bekrachtiging in plaats van integrale nietigheid wordt gestreefd, geeft de rechtspraak een aantal voorbeelden van gevallen waarin nietigheid wordt gekozen terwijl bijvoorbeeld partiële nietigheid wel mogelijk was. Steeds lijkt daarbij de 'handhavingsgedachte' een factor van belang te zijn geweest.

\section{- nietig proeftijdbeding}

HR 8 juli 1987, NJ 1988, 323, (Van Hensbergen/Albers) betrof een overschrijding van de maximale proeftijd. In een arbeidsovereenkomst tussen werkgever Van Hensbergen en werknemer Albers was een proeftijd opgenomen van 3 maanden. Op grond van de wet (art. I639n lid $3 \mathrm{BW}$, thans art. 7:652 BW) gold een maximum proeftijd van 2 maanden. Van Hensbergen ontsloeg Albers binnen 2 maanden. Albers beriep zich op de nietigheid van de bedongen proeftijd, hetgeen gevolgen heeft voor de geldigheid van het ontslag. Van Hensbergen voerde aan dat de overeengekomen proeftijd moest worden geconverteerd in een proeftijd van 2 maanden. Daarmee lag de vraag voor of sprake was van een 'ijzeren proeftijd' waardoor geen ruimte bestaat voor conversie van de proeftijd van 3 maanden in een proeftijd van 2 maanden. De Hoge Raad bekrachtigde het oordeel van de rechtbank dat conversie in dit geval niet mag worden toegepast. Dat houdt in dat het overeengekomen nietige proeftijdbeding niet wordt omgezet in een geldig beding en dat er dus rechtens geen proeftijd tot stand is gekomen:

'Vooropgesteld moet worden dat voor conversie als door het middel hier op haar plaats
geacht - naar de bewoordingen van art. 30208 nieuw BW (art. 3:42 BW, JK en CS) -
vereist is dat de strekking van het nietige beding in zodanige mate beantwoordt aan
die van een ander, als geldig aan te merken beding dat aangenomen moet worden dat
dit laatste beding zou zijn tot stand gekomen indien van het eerstgenoemde wegens
zijn ongeldigheid was afgezien. Daarbij komt het evenwel - anders dan het middel
tot uitgangspunt neemt - niet aan op veronderstelde, al of niet erkende, subjectieve
partijbedoelingen, maar op objectieve factoren, waaronder hier in het bijzonder van

46. C.H. Sieburgh, Tertium Datur, Deventer 2004 en 'Western Contract Law', in: M. Bussani \& F. Werro, European Private Law. A Handbook, München 2009, p. I88-I95. 
belang zijn de aard van het nietigheidsvoorschrift van art. I639n lid 3, het stelsel van de wettelijke regeling van de arbeidsovereenkomst en de in dat kader in aanmerking komende eisen van redelijkheid en billijkheid.' 47

De reden om conversie te weigeren hangt samen met de keuze om de maximale proeftijd van 2 maanden te handhaven. Een werkgever die een te lange proeftijd bedingt en als ergst mogelijk rechtsgevolg heeft te vrezen dat een proeftijd resteert die wettelijk is toegestaan, heeft weinig reden om in de toekomst zich te onthouden van het bedingen van een te lange proeftijd. Met behulp van de rechter krijgt hij dan immers tenminste de proeftijd die is toegestaan:

'In het licht van de wetsgeschiedenis, (...), moet ervan worden uitgegaan dat aan lid 3 daarvan (art. I639n, JK en CS), voor zover hier van belang, de gedachte ten grondslag ligt dat er een waarborg behoort te zijn dat de werknemer in elk geval niet langer dan twee maanden verstoken kan blijven van de bescherming, hem geboden door de wettelijke regeling omtrent ontslag. Aan deze strekking zou worden tekort gedaan, indien een werkgever die bijv., zoals hier, een proeftijd voor een duur van drie maanden in de arbeidsovereenkomst doet opnemen, daarvan geen andere gevolgen zou hebben te vrezen dan dat een proeftijd voor de hoogst toelaatbare duur van twee maanden geldt, terwijl de werknemer die binnen de bedongen proeftijd, doch na verstrijken van de hoogst toelaatbare duur met een beroep op het beding wordt ontslagen, zich tegen dit beroep slechts afdoende zal kunnen verweren bij voldoende kennis van de wettelijke regeling, welke kennis bij werknemers niet zonder meer mag worden verondersteld.' (curs. JK en CS) ${ }^{48}$

In de conclusie voor het arrest wees A-G Mok uitdrukkelijk op de strekking van de wettelijke beperking van de proeftijd om de werknemer te beschermen. Het toelaten van conversie zou de handhaving van de beschermende regel beperken:

'De afweging die in art. I639n ligt besloten - proeftijd in het belang van de werkgever, maar door nietigheid gefunctioneerde beperking daarvan in het belang van de werknemer - brengt m.i. mee dat het streng handhaven van die beperkingen, en dus ook van de sanctie daarop, om redenen van redelijkheid en billijkheid geboden is.' (curs. JK en CS) ${ }^{49}$

Een beroep op partiële nietigheid (de proeftijd valt uiteen in een geldig deel van 2 maanden en een nietig deel van I maand) zou op grond van dezelfde benadering evenmin toegelaten worden..$^{\circ}$ Hiermee is gekozen voor de preventieve werking van

47. HR 8 juli I987, NJ I988, 323 m.nt. P.A. Stein (Van Hensbergen/Albers), r.o. 3.

48. HR 8 juli I987, NJ I988, 323 m.nt. P.A. Stein (Van Hensbergen/Albers), r.o. 3.

49. Conclusie voor HR 8 juli I987, NJ I988, 323 m.nt. P.A. Stein (Van Hensbergen/Albers), onder 4.3.

50. Zie ook Asser/Heerma van Voss $7-V^{\star}$ 2008, nr. 218. 
integrale nietigheid ${ }^{\mathrm{I}}$ van het desbetreffende beding. Interessant is dat voor het niettoelaten van de conversie niet de bedoelingen van partijen beslissend zijn, maar de objectief vaststelbare kenmerken van de geschonden wettelijke regeling en de daaraan verbonden (dus eveneens objectieve) redelijkheid en billijkheid.

\title{
- nietig overwerkbeding
}

Afgezien van het proeftijdbeding, zijn ons geen gevallen bekend waarin de Hoge Raad bij de vraag naar de toelaatbaarheid van partiële nietigheid of conversie heeft verwezen naar de preventieve werking van een integrale nietigheid en in het verlengde daarvan de handhaving van de norm. Wel heeft de Hoge Raad in zijn arrest van I4 januari 2000 geoordeeld dat het in de overeenkomst bepaalde omtrent het salaris en het overwerk niet als één geheel mag worden beschouwd en dat, in geval het beding omtrent het overwerk voor de werknemer minder gunstig zou uitvallen dan de CAO regeling ten aanzien van het overwerk, de CAO regeling daarvoor in de plaats treedt (wettelijke conversie op grond van artikel I 2 lid I, $2^{\mathrm{e}}$ zin Wet op CAO). 52 Hijma wijst er in zijn noot bij het arrest op dat niet ondenkbaar is dat het beding over het salaris en het beding over het overwerk onverbrekelijk met elkaar samenhangen. De nietigheid van het overwerkbeding zou dan de nietigheid van het salarisbeding impliceren. Dit zou echter meebrengen dat een werknemer die zich met succes beroept op de nietigheid van het overwerkbeding het gevaar loopt er wat betreft zijn salaris op achteruit te gaan. Dat gevaar staat in de weg aan de handhaving van de in de CAO neergelegde overwerkregeling:

\begin{abstract}
'Voor cruciaal houd ik de overweging dat een beschermingsregel slechts effectief kan en zal zijn, indien de beschermde partij deze kan benutten zonder voor repercussies (hier: een forse terugval in loon) te moeten vrezen. Op deze rechtspolitieke grond zal een in de individuele arbeidsovereenkomst gelegd verband waar mogelijk als "verbrekelijk" worden beschouwd; de gemaakte loonafspraak blijft dan in stand. Vergelijk HR 8 juli I987, NJ I988, 232 m.nt. PAS (Van Hensbergen/Albers), in welk arrest de Raad met betrekking tot het verwante leerstuk der conversie (art. 3:42 BW) overweegt dat het niet aankomt op subjectieve partijbedoelingen maar op objectieve factoren, zoals de aard van het overtreden nietigheidsvoorschrift, het stelsel van de betrokken wettelijke regeling en de in dat kader in aanmerking komende eisen van redelijkheid en billijkheid.' (curs. JK en CS) 53
\end{abstract}

- nietige borgtocht

Wat betreft het in art. 7:858 BW gestelde geldigheidsvereiste voor de borgtocht aangegaan buiten beroep of bedrijf, inhoudende dat het bedrag van de verbintenis bij

5I. Wij bedoelen met 'integrale nietigheid' dus niet de nietigheid van de gehele overeenkomst, maar van de desbetreffende bepaling in de overeenkomst. Nietigheid van de gehele overeenkomst zal in veel gevallen de door de geschonden regeling beschermde partij (de werknemer, huurder, consument) juist benadelen. Zie ook Asser/Hartkamp 4-II (2005), nr. 49I.

52. HR I4 januari 2000, NJ 2000, 273 m.nt. J. Hijma (Boonen/Quicken).

53. J. Hijma, noot bij HR I4 januari 2000, NJ 2000, 273 (Boonen/Quicken), onder 6. 
het aangaan van de borgtocht dient vast te staan en bij het ontbreken daarvan in een geldig maximum-bedrag moet zijn uitgedrukt, heeft de Hoge Raad overwogen dat:

'deze bepaling ertoe (strekt) te bevorderen dat degene die een particuliere borgtocht aangaat, zich niet alleen van de aard doch ook van de omvang van het aanvaarde risico bewust is.'

De dwingendrechtelijke, absolute nietigheid heeft daarmee de strekking de wederpartij van de borg (schuldeiser van de hoofdschuldenaar) aan te sporen om aan de borg duidelijk te maken voor welk risico de borg de overeenkomst sluit. Ook hier wordt de nietigheid derhalve ingezet ter aansporing en daarmee ter handhaving van de gedragsnorm. 54

- verhouding nietigheid beding en rest overeenkomst

Om de hiervoor bedoelde integrale nietigheid van een beding daadwerkelijk preventieve werking te laten hebben, is het wel van belang te zien dat de overeenkomst waarvan het beding onderdeel uitmaakt overigens in stand blijft. Het integraal nietige beding dient derhalve zoveel als mogelijk te worden beschouwd als in verbrekelijk verband staand met de gehele overeenkomst. Een ondernemer die betoogt dat hij zonder het proeftijdbeding de rest van de overeenkomst evenmin zou hebben gesloten, om welke reden de gehele overeenkomst nietig is, dient in dat betoog niet gevolgd te worden. Voor het geval een beding in algemene voorwaarden nietig is wordt deze benadering voorgeschreven door art. 6 lid I van de richtlijn 93/I3/EEG.

\section{Restitutierechtelijke gevolgen van nietigheid}

Dat echter ook bij het leerstuk van de nietigheid de 'handhavingsgedachte' bepaald geen hoofdrol heeft gespeeld, blijkt uit de restitutierechtelijke gevolgen van de nietigheid. In veel gevallen waarin een (partiële) nietigheid wordt vastgesteld, leidt dat tot verplichtingen tot ongedaanmaking. De benadering van het ongedaanmakingsleerstuk in Nederland, van zowel de wetgever als de rechtspraak, is gericht op het vermijden van verrijking: de partij die zonder rechtsgrond een prestatie heeft ontvangen mag deze niet behouden. Het is niet gericht op het handhaven van de werking van de regel waarvan de schending de nietigheid meebrengt.

In HR 28 juni I99I, NJ I992/787 (Verkerk/Van der Veen q.q.) was aan een bouwbedrijf dat zonder vergunning arbeidskrachten had uitgeleend - een strafrechtelijk vergrijp - een waardevergoeding toegekend op basis van de overeengekomen uurlonen van de ter beschikking gestelde arbeidskrachten. De Hoge Raad liet deze toewijzing in stand en overwoog:

54. Zie ook Conclusie Plv. P-G De Vries Lentsch, onder 9. Anders Asser/Van Schaick 5-IV (2004), nr. 209. 
'In geval van nietigheid van een overeenkomst zullen de ter nakoming van die overeenkomst reeds verrichte prestaties in beginsel op grond van onverschuldigde betaling kunnen worden teruggevorderd dan wel zal daarvoor een vergoeding kunnen worden gevorderd, (...) een en ander ongeacht de grond van deze nietigheid. Dat wordt niet anders in een geval als het onderhavige waarin het gaat om een overeenkomst met een verboden strekking en de vordering wordt ingesteld door degene die de overtreding van het verbod in de eerste plaats heeft beoogd en nagestreefd. ${ }^{55}$

Dat het Nederlandse privaatrecht hiermee defacto uitvoering geeft aan nietige afspraken, wordt minder bezwaarlijk gevonden dan de gedachte dat de gedaagde dat wat hij heeft ontvangen zou mogen behouden, 'doch daarvoor per saldo generlei offer behoeft te brengen'. ${ }^{6}$ Anders gezegd: de handhavingsgedachte wordt opzij gezet door de vanuit privaatrechtelijk oogpunt belangrijker geachte verrijkingsgedachte.

In dit kader zij aangetekend dat in de Duitse en de Engelse jurisprudentie overwegingen van handhaving in dit soort kwesties nu en dan wel beslissend zijn geweest. Zo overwoog Lord Justice Schiemann in Awwad v Garaghty \& Co.:

'If the court, for reasons of public policy refuses to enforce an agreement that a solicitor should be paid it must follow that he cannot claim on quantum meruit. (...) In the present case, what public policy seeks to prevent is a solicitor continuing to act for a client under a conditional normal fee arrangement. That is what Miss Geraghty did. That is what she wishes to be paid for. Public policy decrees that she should not be paid. ${ }^{57}$

Mede op grond van dezelfde gedachte heeft het Duitse Bundesgerichtshof de vordering afgewezen van een woekeraar, die een waardevergoeding vorderde voor het door hem verleende krediet. Immers, indien wel een waardevergoeding gevorderd zou kunnen worden, dan: '(...) könnte der Wucherer risikolos arbeiten. ${ }^{5} 8$ Echter, ook in Duitsland is deze gedachtegang niet onomstreden. Dannemann kent de handhavingsgedachte een centrale rol toe bij de beslissing of een verrijkingsactie toegestaan moet worden of niet. Daarentegen heeft Medicus betoogd dat het onthouden van een verrijkingsactie in dit soort situaties slechts kan worden verklaard vanuit de - in zijn ogen achterhaalde - gedachte dat de woekeraar dient te worden gestraft voor zijn onbetamelijke gedrag. 59

55. R.o. $3 \cdot 3$.

56. Parl. Gesch. Boek 6, p. 820. Zie voor het oude recht ook HR 7 november I935, NJ I936/239 en HR 25 juni I937, NJ I937/II28.

57. Awwad v Garaghty \& Co. [200I] QB 570 at 596. Zie voor verdere verwijzingen H.J. van Kooten, Restitutierechtelijke Gevolgen van Ongeoorloofde Overeenkomsten, Deventer 2002, p. 247-25I.

58. BGH NJW I983, I420 op p. I423.

59. Zie Van Kooten, Restitutierechtelijke Gevolgen van Ongeoorloofde Overeenkomsten, a.w., p. I8I met verdere verwijzingen. 
Interessant is, dat de Hoge Raad in het zojuist vermelde arrest van 28 juni I99I van de gelegenheid gebruik maakte om ten overvloede te overwegen dat de regel van ongedaanmaking van de prestaties die zijn verricht op grond van een nietige overeenkomst, uitzonderingen kent:

'Wel kan zich het geval voordoen dat toewijzing van een zodanige vordering - in de bewoordingen van art. 6:2 lid $2 \mathrm{BW}$ - in de gegeven omstandigheden naar maatstaven van redelijkheid en billijkheid onaanvaardbaar zou zijn (Parlementaire Geschiedenis Boek 3, Inv. 3, 5 en 6, p. II68-II69, telkens punt a), (...). ${ }^{60}$

Op de mogelijke uitwerking van deze gedachte komen wij hierna terug.

\section{- Principles of European Contract Law (PECL)}

Volgens de in de PECL gevolgde systematiek worden het oordeel over de 'ineffectiveness' (een neutraal woord voor ongeldigheid wegens strijd met fundamentele beginselen of dwingend recht) en het oordeel over de daaraan te verbinden gevolgen ten aanzien van ongedaanmaking en schadevergoeding met elkaar in verband gebracht. ${ }^{61}$ Artikel 15:104 PECL bepaalt dat hetgeen is gepresteerd op grond van de ongeldige overeenkomst in beginsel over en weer vatbaar is voor een vordering tot ongedaanmaking. Het antwoord op de vraag óf de ongedaanmakingsvordering moet worden toegewezen en of de wederpartij óók ongedaan moet maken, wordt gevonden met in achtneming van zes factoren die ook beslissend zijn voor de vraag of (en zo ja, in hoeverre) een overeenkomst die in strijd is met een dwingendrechtelijke regel ongeldig ('ineffective') is. Deze in artikel I4:I02 lid 3 PECL genoemde factoren zijn: I. de strekking van de geschonden regel, 2. de groep van personen ter bescherming van wie de regel strekt, 3. de sanctie die de geschonden regel (afgezien van eventuele ongeldigheid) oplegt, 4 . de ernst van de schending, 5. de vraag of de schending opzettelijk plaatsvond en 6 . de 'closeness of the relationship' (de onmiddellijkheid van het verband) tussen de overeenkomst en de schending. ${ }^{62}$ In artikel 15:I04 lid 3 PECL wordt geëxpliciteerd dat ongedaanmaking kan worden geweigerd aan een partij die de reden van de ongeldigheid kende of behoorde te kennen. ${ }^{63}$

Door in beginsel te kiezen voor de bevoegdheid ongedaanmaking te vorderen, kiezen de PECL, anders dan bijvoorbeeld het Engelse en het Franse recht, niet voor het uitgangspunt dat partijen bij een verboden overeenkomst in de toestand worden gelaten waarin de rechter hen aantreft. Dit uitgangspunt wordt gerelativeerd door de flexibele benadering die artikel 15:104 lid 2 PECL biedt voor het vellen van een uiteindelijk oordeel over wel of geen ongedaanmaking. Zij maakt het mogelijk dat,

6o. HR 28 juni I99I, NJ I992, 787 m.nt. C.J.H. Brunner (Verkerk/Van der Veen q.q.), r.o. 3·3.

6r. In dit opzicht wijkt de DCFR af van de PECL. Voor de rechtsgevolgen van een vastgestelde ongeldigheid wordt verwezen naar de regels over ongerechtvaardigde verrijking (Book VII DCFR). Zie art. II. $-7: 303$ DCFR.

62. Zie ook art. II.-7:302 DCFR.

63. Zie A.C. van Schaick in: H. Schelhaas e.a. (eds.), The Principles of European Contract Law (part III) and Dutch Law, Den Haag 2006, p. 243-247. 
indien dat aangewezen is, ongedaanmaking (aan beide partijen of aan een van hen) geweigerd kan worden.

\subsection{Intellectueel eigendomsrecht}

Anders dan in ons gemene verbintenissenrecht (zie hiervoor onder 2.I.2), bestaat in ons intellectuele eigendomsrecht een 'echt' recht op winstafdracht. Zo bepaalt artikel 43 lid 3 van de Rijksoctrooiwet dat de inbreukmaker in plaats van tot schadevergoeding kan worden veroordeeld tot winstafdracht. Gaat het in de Rijksoctrooiwet nog om een alternatief recht - óf schadevergoeding óf winstafdracht - in de Auteurswet leek aanvankelijk zelfs een cumulatief recht op winstafdracht te zijn opgenomen. ${ }^{64}$ Artikel $27 \mathrm{a}$, lid I Auteurswet bepaalt dat de rechthebbende op een auteursrecht van de inbreukmaker 'naast schadevergoeding' kan vorderen dat de inbreukmaker wordt veroordeeld de 'genoten winst af te dragen'. De kans op dubbeltellingen is dan reëel. Immers, de winst van de inbreukmaker benadert dikwijls de schade (in de vorm van winstderving) van de rechthebbende. Zou inderdaad onder de Auteurswet een recht op zowel winstafdracht als schadevergoeding bestaan, dan zou deze regeling gedeeltelijk punitief zijn. Daarvan uitgaande observeerde Brunner dat het 'punitieve karakter (...) moeilijk in overeenstemming te brengen (is) met de uitgangspunten van ons schadevergoedingsrecht, maar (...) in de wereld van de intellectuele eigendom kennelijk nodig geacht (wordt) om inbreuk tegen te gaan'. ${ }_{5}$

In HBS/Danestyle heeft de Hoge Raad echter uitgemaakt dat ook onder de Auteurswet het recht op winstafdracht niet náást, maar als alternatief voor het recht op schadevergoeding is bedoeld. Opvallend daarbij is dat de Hoge Raad refereerde aan het algemene stelsel van het vermogensrecht:

'indien, zoals hier, behalve voor vergoeding van schade bestaande in gederfde licen-
tievergoedingen tevens afdracht van winst wordt gevorderd, brengt een redelijke, bin-
nen het algemene stelsel van het vermogensrecht passende, uitleg van die bepaling
mee dat niet meer dan een bedrag gelijk aan het grootste van die beide bedragen kan
worden toegewezen. ${ }^{66}$

Het gevaar van dubbeltelling is daarmee weggenomen. Is de winst van de inbreukmaker hoger dan de door de rechthebbende geleden schade, dan dient hij (alleen) de winst af te dragen.

64. Zie de toelichting op het amendement van Tweede Kamerlid Koetje, kamerstukken II, I987/88, I9 92I nr. II ('ook wanneer de gemaakte winst niet geheel kan worden toegerekend aan het inbreukmakend voorwerp zelf heeft de rechter op basis van dit artikel de mogelijkheid de vordering tot winstafdracht gedeeltelijk toe te wijzen, gecumuleerd met een schadevergoeding (curs. JK en CS)).

65. Zie de noot van Brunner onder HR 24 december 1993, NJ 1995/42I (Waeyen-Scheers/Nous).

66. HR I4 april 2000, NJ 2000, 489 m.nt. DWFV (HBS/Danestyle), r.o. 3·3·5. 
Ook in ons merkenrecht bestaat een 'echt' recht op winstafdracht. In de toelichting bij het relevante artikel van de Benelux Merken Wet - dat inmiddels is vervangen door het op dit punt inhoudelijk gelijke Benelux Verdrag Inzake de Intellectuele Eigendom (merken en tekeningen of modellen) - wordt erkend dat het recht op winstafdracht 'uitgaat boven hetgeen in civielrechtelijke procedures als regel is toegestaan'. Daarmee is beoogd een handhavingsdoel te dienen: 'de vorderingsmogelijkheid is opgenomen om te voorkomen dat de pleger van moedwillige inbreuk ondanks een rechterlijke veroordeling baat uit zijn onrechtmatig handelen trekt. ${ }^{67}$ De sanctie van winstafdracht is in het merkenrecht echter uitdrukkelijk beperkt tot gevallen van kwade trouw, dat wil zeggen, 'moedwillige inbreuken'.

Hoewel de verplichting tot winstafdracht in ons intellectuele eigendomsrecht in voorkomende gevallen evident verder gaat dan de verplichting tot vergoeding van de veroorzaakte schade, zij aangetekend dat de dreigende werking die daarvan uitgaat, beperkt is. Indien succesvol aangesproken, raakt de inbreukmaker zijn wederrechtelijk verkregen voordeel kwijt. Het moge zo zijn dat zijn inspanningen daarmee onbeloond zijn geweest, een daadwerkelijke boete is hierin slechts met moeite te ontwaren. Advocaat-Generaal Langemeijer spreekt in dit kader van een 'neutrale eindtoestand', waarin de inbreukmaker 'per saldo geen voordeel overhoudt van de door hem begane inbreuk (...) maar ook geen nadeel'. ${ }^{68}$ De handhaving van intellectuele eigendomsrechten is door de figuur van winstafdracht dan ook hooguit in die zin gediend, dat in voorkomende gevallen de bestaande economische prikkel tot het plegen van een inbreuk aan de inbreukmaker wordt ontnomen. ${ }^{69}$

\subsection{Goederen- en faillissementsrecht}

Bij 'handhaving' door middel van het goederenrecht, kan men in de eerste plaats denken aan de regels van derdenbescherming tegen de beschikkingsonbevoegdheid van de vervreemder. Op het eerste gezicht lijken deze regels het resultaat van een afweging tussen enerzijds de bescherming van het recht van de eigenaar om niet in zijn bezit gestoord te worden en anderzijds de bescherming van gerechtvaardigd vertrouwen van verkrijgers, waarzonder het handelsverkeer niet behoorlijk kan functioneren. De werkelijke afweging is uiteraard aanzienlijk genuanceerder. Dat daarbij ook de handhavingsgedachte een rol van betekenis speelt, is bijvoorbeeld betoogd door Nieuwenhuis:

67. Memorie van Toelichting bij het Protocol van 2 december I992, artikelsgewijze toelichting bij het toenmalige vierde lid, thans het vijfde lid, van artikel I3.A BMW. Art. I3.A, lid 5 BMW is inmiddels vervangen door art. 2.2I lid 4 van het Benelux Verdrag Inzake de Intellectuele Eigendom (merken en tekeningen of modellen).

68. Benelux-Gerechtshof II februari 2008, RvdW 2008, 293; NJ 2008, 535 m.nt. Chielen (Ondeo Nalco/Michel Company), conclusie, nr. 2.I6.

69. Zie ook T.E. Deurvoorst, Schadevergoeding, voldoening van een redelijke gebruiksvergoeding en winstafdracht bij inbreuk op intellectuele eigendomsrechten, Deventer 1994, p. I73. 
'(Tegenover het verkeersbelang) staat het argument van de misdaadbestrijding dat de laatste jaren aan gewicht heeft gewonnen. Diefstal en verduistering floreren dankzij het feit dat er kopers zijn van gestolen en verduisterde zaken. Het moet hun niet te gemakkelijk worden gemaakt. Dit pleit voor het adagium: laat de derde hand weten wat de tweede hand deed. ${ }^{70}$

Het is aannemelijk dat de Hoge Raad bij het invullen van de onderzoeksplicht van de derde-verkrijger tenminste heeft meegewogen welk positief neveneffect de beperking van de derdenbescherming zou kunnen hebben op de bestrijding van misdaad. Dit kan mede de strenge leer verklaren die de Hoge Raad hanteert ten aanzien van verkrijgers van auto's. Door kopers die verzuimen de autopapieren te controleren derdenbescherming te ontzeggen - hoewel strikt genomen geen 'straf' maar een ingehouden voordeel - worden zij aangemoedigd hun onderzoeksplicht zorgvuldig uit te voeren. ${ }^{7 \mathrm{I}}$ Dat maakt het vervolgens lastiger voor autodieven om hun gestolen goed aan de man te brengen.

Verder kan worden gewezen op de specifiek in het goederenrecht voorkomende nietigheden, waarbij, net als wij hiervoor in het kader van de algemene leer der overeenkomsten bespraken, de vraag kan spelen in hoeverre de nietige rechtshandeling geconverteerd kan worden in een geldige rechtshandeling. Kan bijvoorbeeld een overdracht tot zekerheid in strijd met het fiduciaverbod worden geconverteerd in een rechtsgeldig pandrecht? Bij de beantwoording van deze vraag kan de handhavingsgedachte een rol spelen. Zo vindt Struycken beslissend of de betrokken partijen bewust hebben getracht het fiduciaverbod te ontduiken. Is dat zo, dan acht hij een 'ontmoedigingsbeleid' op zijn plaats en conversie daarom niet toelaatbaar.72 Zoals wij ook hiervoor hebben aangetekend, gaat van de 'sanctie' van nietigheid echter slechts in beperkte mate een ontmoedigende (en daarmee 'handhavende') werking uit. 73

Een meer tot de verbeelding sprekende vorm van handhaving door het goederenrecht regelt artikel 3:194 lid 2 BW. Daarin is bepaald dat een deelgenoot in een gemeenschap die opzettelijk het bestaan van een gemeenschappelijk goed verzwijgt, dat goed zoek maakt of verborgen houdt, zijn aandeel daarin verbeurt:

70. J.H. Nieuwenhuis in zijn annotatie onder HR 4 april I986, Ars Aequi 35 (I986), p. 793 (Apon/Bisterbosch).

7I. Zie met name HR 7 oktober 2005, NJ 2006, 35I, m.nt. WMK, Ars Aequi 55 (2006), m.nt. S.C.J.J.Kortmann, VRA 2006/3, m.nt. A.F. Salomons (Coppes/Van de Kolk), in het bijzonder de conclusie van A-G Huydecoper voor dat arrest.

72. T.H.D. Struycken, De Numerus Clausus in het Goederenrecht, Deventer 2007, p. 679-68I.

73. Daarbij komt dat het hier hooguit de handhaving betreft van een in het goederenrecht zelf neergelegde regel - het fiduciaverbod - waarvan bovendien twijfelachtig is of hij als 'normatief' moet worden beschouwd. 
'Een deelgenoot die opzettelijk tot de gemeenschap behorende goederen verzwijgt, zoek maakt of verborgen houdt, verbeurt zijn aandeel in die goederen aan de andere deelgenoten.' 74

Dit is een 'zuivere' strafbepaling. Opmerkelijk is dan ook dat in de Parlementaire Geschiedenis niet uitgelegd wordt waarom deze bepaling is opgenomen. De Toelichting Meijers verwijst alleen naar een opstel van Meijers zelf, waarin hij bevestigt dat het artikel als straf is bedoeld en vervolgens de historische wortels van het artikel beschrijft. ${ }^{75}$ Aannemelijk is echter dat de belangrijkste rechtvaardiging voor het bestaan van de rechtsregel van artikel 3:194 lid 2 BW daarin is gelegen, dat het een effectief middel biedt om het verbod op diefstal en verduistering te handhaven. Zo ook W. Snijders:

'De bepaling is weliswaar wegens haar strafkarakter uitzonderlijk, maar het is moeilijk deelgenoten op andere wijze effectief te beschermen tegen een vorm van bedrog die in de praktijk maar al te gemakkelijk is. ${ }^{76}$

In het faillissementsrecht zou men - met een beetje goede wil - een handhavend element kunnen ontwaren in de faillissementspauliana. Uit de artikelen 42 en $5 \mathrm{I}$ van de Nederlandse Faillissementswet volgt dat een rechtshandeling die vóór de faillietverklaring door de failliet is verricht, kan worden vernietigd indien de partijen bij die rechtshandeling wisten of behoorden te weten dat daarvan benadeling van de schuldeisers het gevolg zou zijn. Hij die als gevolg van de vernietigde rechtshandeling een prestatie heeft ontvangen, dient deze aan de boedel te restitueren. Deze verplichting beperkt zich niet tot het bedrag waarmee de schuldeisers ten tijde van de handeling in fraudem creditorum zijn benadeeld. Koopt men bijvoorbeeld een auto met een waarde van $€$ Iooo voor $€ 250$ in de wetenschap dat het faillissement van de verkoper aanstaande is, dan kan de restitutieverplichting niet worden afgewend door het waardeverschil van $€ 750$ aan de curator over te maken. Na vernietiging kan de curator de auto terugvorderen. Op zijn beurt is de curator slechts gehouden tot teruggave van de koopsom van $€ 25$ o voor zover de boedel door die betaling ook daadwerkelijk is gebaat. Heeft de failliet die koopsom echter vóór faillissement verbrast, dan rest de koper niet meer dan een concurrente vordering. ${ }^{77}$ Uit de parlementaire geschiedenis bij artikel 5I Fw wordt niet onmiddellijk duidelijk waarom de koper niet kan volstaan met het 'compenseren' van het verschil tussen de koopsom en de werkelijke waarde. Het is echter aannemelijk dat daarbij (mede) de handhavingsgedachte een rol heeft gespeeld. Door het risico dat de waarde van

74. Zie ook art. 4:I84 lid 2 sub c BW, dat de erfgenaam die opzettelijk goederen uit de nalatenschap zoek maakt, verbergt of op andere wijze aan het verhaal van schuldeisers van de nalatenschap onttrekt, bestraft met aansprakelijkheid voor de schulden van de nalatenschap (ondanks beneficiaire aanvaarding).

75. E.M. Meijers, 'artikel IIIo B.W.', WPNR 3126 en 3128 (I929).

76. W. Snijders, 'Verleden en Toekomst van art. 3:194 lid 2' in Yin-Yang (Van Mourik-bundel), Deventer 2000, p. 36r.

77. Zie B. Wessels, Gevolgen der Faillietverklaring (2), Deventer 2007, p. I59, nr. 3259. 
de prestatie niet behouden blijft op de wederpartij van de failliet te laten rusten, wordt zij ontmoedigd mee te werken aan paulianeuze handelingen. In het Duitse recht wordt deze ratio wel erkend. Dat de aangesprokene niet kan volstaan met een 'Saldierung auf die bloße Leistungsdifferenz', wordt onder meer gerechtvaardigd door het feit dat bekendheid met de financiële nood voldoende waarschuwing moet zijn om met de aanstaande failliet geen onevenwichtige rechtshandelingen aan te gaan..$^{8}$

In de sfeer van het faillissementsrecht liggen voorts de artikelen 2:I38 en $248 \mathrm{BW}$, ingevoerd als onderdeel van de derde misbruikwet. Zij regelen, in geval van faillissement van een rechtspersoon een bewijsvermoeden inhoudende dat de bestuurder die geen behoorlijke administratie heeft bijgehouden of niet aan de verplichting tot openbaarmaking van de jaarrekening heeft voldaan, het faillissement (mede) heeft veroorzaakt. Deze bepalingen verslechteren de bewijspositie van de bestuurder zodanig, dat hun uitwerking in de praktijk vrijwel altijd als 'straf' zal worden ervaren. Bovendien geldt de aansprakelijkheid voor het gehele faillissementstekort. Onze wetgever heeft in dit kader uitdrukkelijk onderkend dat het tekort de schade die door het onbehoorlijke bestuur is veroorzaakt, kan overtreffen. Dat werd aanvaardbaar geacht, omdat de regeling zou kunnen bijdragen aan de handhaving van de op bestuurders rustende verplichtingen. Zie de Memorie van Toelichting bij de artikelen 2:138 en $248 \mathrm{BW}$ :

'Om de wettelijke regeling (van de bestuursaansprakelijkheid) meer effect te doen hebben, is verbetering daarvan noodzakelijk. Ook aan de preventieve werking die van de regeling uitgaat komt zulks ten goede. Bestuurders van vennootschappen die weten dat zij in geval van faillissement daadwerkelijk door de curator aangesproken kunnen worden en dan niet steeds door de rechtspersoonlijkheid van de vennootschap worden beschermd, zullen in hun beleid en beheer meer verantwoord te werk gaan.' (curs. JK en $\mathrm{CS})^{79}$

De derde misbruikwet introduceerde daarmee, naast de strafrechtelijke en vennootschapsrechtelijke handhavingsmechanismen, een civielrechtelijke component ten behoeve van de bestrijding van misbruik van rechtspersonen. ${ }^{80}$ Daarbij zij echter aangetekend dat de wetgever niet heeft beoogd de tekortschietende bestuurder aansprakelijk te houden voor schade waarvan vaststaat dat hij haar niet kan hebben veroorzaakt. Wanneer in de loop van de procedure blijkt dat het faillissementstekort de daadwerkelijk veroorzaakte schade overstijgt, kan de rechter op die grond de aansprakelijkheid van de bestuurder matigen (artikel 2:138 lid 4 en 248 lid 4 BW).

78. Zie Münchener Kommentar zur Insolvenzordnung, München 2002, § I32, Rdnr. 29. Vgl. ook G. van Dijck, Revisie van een Relict, Nijmegen 2006, p. III, die de vraag opwerpt of de faillissementspauliana een afschrikkende werking moet worden toegedicht 'omwille van het algemeen belang'.

79. MvT, TK I6 63I, nr. 3, p. 3. Zie ook Handelingen II, I985, 6334, waar de minister van Justitie de bedoelde artikelen aanmerkt als 'middel ter bestrijding van misbruik van rechtspersonen'.

8o. Zie hierover nader P. van Schilfgaarde, Misbruik van Rechtspersonen, Deventer I986, in het bijzonder p. 4-6. 
Zie de Memorie van Toelichting, waarin de minister van justitie ten aanzien van deze matigingsbevoegdheid opmerkte:

'In de opzet van het ontwerp is de verplichting tot schadevergoeding vervangen door een verplichting tot vergoeding van het tekort. Dit tekort kan de schade die door het onbehoorlijk bestuur is veroorzaakt overtreffen. Het is niet redelijk de bestuurder aansprakelijk te stellen voor een hoger bedrag dan de schade die door het onbehoorlijke bestuur kan zijn ontstaan. ${ }^{8 \mathrm{r}}$

Kortom, hoewel de derde misbruikwet vanuit de handhavingsgedachte een voor bestuurders ongunstige bewijspositie creëert, is niet de bedoeling van de wetgever geweest om het compensatoire karakter dat in het gemene aansprakelijkheidsrecht voorop staat, voor gevallen van onbehoorlijk bestuur opzij te zetten.

\subsection{Gebods- en verbodsacties: de dwangsom}

Het privaatrechtelijke handhavingsinstrument bij uitstek, is de gebods- en verbodsactie van artikel 3:296 lid I BW, dat bepaalt:

'Tenzij uit de wet, uit de aard der verplichting of uit een rechtshandeling anders volgt, wordt hij die jegens een ander verplicht is iets te geven, te doen of na te laten, daartoe door de rechter, op vordering van de gerechtigde, veroordeeld.'

Het bereik van deze bepaling is groot. Hoewel de bepaling doorgaans in de eerste plaats wordt geassocieerd met vorderingen tot nakoming van overeenkomsten, moeten onder 'verplichtingen' als bedoeld in dit artikel zowel verbintenissen uit overeenkomst als andere rechtsplichten worden begrepen. Uit de schakelbepaling van artikel 3:326 BW volgt bovendien dat artikel 3:296 lid I BW ook buiten het vermogensrecht kan worden toegepast, mits de aard van de betrokken rechtsverhouding zich daar niet tegen verzet.

Via de open norm van artikel 6:162 BW (onrechtmatige daad) in combinatie met de collectieve actie van artikel 3:305a BW, kan in voorkomende gevallen ook naleving worden gevorderd van normen die primair publiekrechtelijk van aard zijn. Een aansprekend voorbeeld is de zaak die aanleiding gaf tot HR 25 februari 1994, NJ 1996, 362 (Sopar/Stichting Reinwater), waar een viertal private Nederlandse milieuorganisaties met succes een gebodsactie instelde tegen een Belgische teerfabrikant. De fabrikant werd veroordeeld om alle voorwaarden van een door de Belgische overheid

8I. MvT, TK I6 63I, nr. 3, p. 5 . 
afgegeven lozingsvergunning na te leven. ${ }^{82}$ Milieuorganisaties maken inmiddels veelvuldig gebruik van ge- en verbodsacties.

Dat overigens de toelaatbaarheid van deze vorm van privaatrechtelijke handhaving van (primair) publiekrechtelijke normen niet door iedereen vanzelfsprekend werd gevonden, moge blijken uit de annotaties van Scheltema en Brunner bij HR I8 december 1992, NJ 1994, I39 (Kuunders/Stichting Natuur en Milieu). Scheltema schrijft daar:

'Het algemeen belang moet niet via het privaatrecht worden behartigd indien juist daarvoor de bestuursrechtelijke weg is aangelegd. (...) Sterker gezegd, er is vanuit het rechtssysteem een sterk argument tegen het toestaan van de privaatrechtelijke weg indien het bestuursrecht een voorziening heeft getroffen. Het zou toch merkwaardig zijn indien alle waarborgen die in het bestuursrecht zijn ingebouwd om de tegenstelling tussen algemeen en individueel belang in evenwicht te houden, niet meer behoeven te gelden indien niet (alleen) de overheid, maar een andere organisatie zich het algemeen belang aantrekt.'

\section{Evenzo Brunner:}

'Ik meen dat er reden is beducht te zijn voor het toekennen van vorderingsrechten uit onrechtmatige daad aan rechtspersonen die het algemeen belang beogen te behartigen en als plaatsvervangers van de overheid civielrechtelijk op de naleving van de wet toezien.'

Ge- en verbodsacties door behartigers van een collectief belang zijn inmiddels echter aan de orde van de dag.

De handhavende kracht van ge- en verbodsacties bestaat met name daarin, dat zij gebruikt kunnen worden om normschendingen te voorkomen nog voordat zij hebben plaatsgevonden, respectievelijk voortdurende normschendingen een halt toe te roepen. Dat een uitgesproken gebod of verbod in praktijk ook daadwerkelijk effectief is, is vooral te danken aan het feit dat zij doorgaans worden versterkt met een dwangsom. ${ }^{83}$ Artikel 6ria lid I Wetboek van Burgerlijke Rechtsvordering (Rv) bepaalt daartoe:

82. Zie verder Rechtbank's-Gravenhage 7 september 2005, NJ 2005, 473 (Stichting proefprocessenfonds Clara Wichmann c.s./Staat), waar de Staat werd verboden om de SGP nog overheidssubsidie te verlenen zolang vrouwen niet op gelijke voet met mannen lid zouden kunnen worden van die partij. De rechtbank was van oordeel dat de Staat in strijd met artikel 7 van het VN-Vrouwenverdrag handelde en dat dit onrechtmatig was jegens vrouwen en mannen die discriminatie op grond van geslacht willen tegengaan. In beroep werd deze uitspraak gedeeltelijk vernietigd: Hof Den Haag 20 december 2007, NJ 2008, I33.

83. Daarnaast kan de rechter op grond van artikel $585 \mathrm{Rv}$ lijfsdwang toestaan. Zie daarover zeer kritisch P.H.J. Körver, 'De lijfsdwang heeft een januskop', Ars Aequi 56 (2007), p. 663-668. 
'De rechter kan op vordering van een der partijen de wederpartij veroordelen tot betaling van een geldsom, dwangsom genaamd, voor het geval dat aan de hoofdveroordeling niet wordt voldaan, onverminderd het recht op schadevergoeding indien daartoe gronden zijn.'

Artikel 6IIc Rv stelt buiten twijfel dat verbeurde dwangsommen toekomen aan de partij die de dwangsomveroordeling heeft verkregen.

In de Gemeenschappelijke Memorie van Toelichting bij de Benelux Overeenkomst houdende eenvormige wet betreffende de dwangsom, wordt uitdrukkelijk gesteld dat de dwangsom niet het karakter van een 'straf' heeft:

'De dwangsom is niet een straf, d.w.z. een strafrechtelijke boete als sanctie op een inbreuk op de openbare orde. Zij ligt geheel op het gebied van het burgerlijk recht. ${ }^{84}$

Ook in onze literatuur wordt aangenomen dat de dwangsom moet worden gezien als een executiemiddel met een zuiver preventief karakter:

'Het dreigen daarmee is uitsluitend middel om tot het werkelijke doel van de dwangsomveroordeling te komen: het beïnvloeden van het toekomstige gedrag van de veroordeelde, om - zo nodig - het (opnieuw) overtreden van de door de rechter bij vonnis vastgestelde civielrechtelijke norm te voorkomen. ${ }^{85}$

Dit onderscheid komt ons al te subtiel voor.

Enerzijds geldt dat juist strafrechtelijke sancties in belangrijke mate een preventief karakter hebben. Hoewel over de functie van ons strafrecht verschillend wordt gedacht, is algemeen aanvaard dat ne peccetur - 'opdat niet misdreven worde' - één van de centrale doelstellingen van ons strafrecht is. ${ }^{86}$ Anderzijds geldt dat de opvordering van dwangsommen ook kan geschieden als daarvan in het individuele geval geen preventief effect meer te verwachten is. Was de dwangsom verbonden aan een verbod op het verrichten van een eenmalige gedraging of een gebod of verbod dat was gelimiteerd in de tijd, dan kan van het verbeurd zijn van de dwangsom na het relevante tijdstip jegens de veroordeelde geen preventieve werking uitgaan. De verbeurte van de dwangsom is in een dergelijk geval louter een 'straf' voor de ongehoorzaamheid aan de uitspraak van de rechter. Wel verdedigbaar is dat een dergelijke verbeurte in zoverre preventief werkt, dat zij de afschrikwekkende werking van dwangsomveroordelingen in algemene zin bevordert ('algemene preventie'). In dat

84. GMvT, Handelingen II I975/76, I3 788, nr. 4, p. I6.

85. M.B. Beekhoven van den Boezem, De Dwangsom in het Burgerlijk Recht, Deventer 2006, p. 7I. Zie ook A.W. Jongbloed, De privaatrechtelijke dwangsom, Nijmegen 2007, p. 26.

86. Zie onder meer Ch.J. Enschedé, Beginselen van Strafrecht, $\mathrm{I}_{2}{ }^{\mathrm{e}}$ druk, bewerkt door M. Bosch, Deventer 2008, p. IO-I2; J.M. van Bemmelen \& Th.W. van Veen, Het materiële strafrecht, $\mathrm{I}_{4}^{\mathrm{e}}$ druk, bewerkt door D.H. de Jong en G. Knigge, Deventer 2003, p. 26-30 en G.J.M. Corstens, Het Nederlands strafprocesrecht, a.w., p. Io. 
opzicht verschilt de verbeurte van dwangsommen echter niet wezenlijk van strafrechtelijke bestraffing.

Evenmin kan worden gezegd dat de normovertreding die met de dwangsom wordt gesanctioneerd, wezenlijk anders is dan de normovertredingen waarop ons strafrecht ziet. Weliswaar wordt de dwangsom opgelegd door een civiele rechter en wordt zij neergelegd in een civielrechtelijk vonnis, ${ }^{87}$ de norm zelf heeft een publiek karakter: 'gij zult de rechter gehoorzamen. ${ }^{88}$ Deze norm is naar haar aard niet anders dan bijvoorbeeld de strafrechtelijk gesanctioneerde norm dat bevelen van een opsporingsambtenaar dienen te worden opgevolgd (art. I84 Sr). Juist omdat de normovertreding los staat van de civielrechtelijke verhouding tussen partijen, wordt de verschuldigdheid van dwangsommen niet opgeheven door een andersluidend oordeel in de bodemprocedure. ${ }^{89}$ Is de dwangsom verbonden aan een door de rechter uitgesproken verbod, dan zou men bovendien kunnen zeggen dat de dwangsom dient ter handhaving van het verbod op eigenrichting, dat eveneens publiekrechtelijk van aard is..$^{\circ}$ Zo ook A-G Ten Kate in zijn conclusie voor HR 22 december I989, NJ I990, 434 (Kempkes/Samson):

'Zoals uiteengezet, gaat het hier om handhaving van de uitgesproken voorlopige ordening. In voormeld licht blijft anders handelen een vorm van op straffe van verbeurte van een dwangsom verboden "eigen richting".

Zelfs M. Beekhoven van den Boezem, een uitgesproken vertegenwoordigster van het standpunt dat de dwangsom louter preventief zou zijn, erkent dat de blijvende verschuldigdheid van dwangsommen na een andersluidend oordeel in de bodemprocedure 'nog slechts een bestraffing (vormt) voor het feit dat de kortgedingveroordeling werd overtreden'. ${ }^{\text {I }}$

\section{Evaluatie}

\section{I Uitgangspunt: de beperkte rol van de handhavingsgedachte in het Nederlandse privaatrecht}

Het voorgaande maakt duidelijk dat handhaving in de betekenis die wij daaraan toekennen in het geldende privaatrecht een ondergeschikte rol speelt. In veel gevallen

87. Vgl. M.B. Beekhoven van den Boezem, De Dwangsom in het Burgerlijk Recht, a.w., p. 66.

88. Evenzo: E. Gras, 'De dwangsom als sanctie op tegenover de overheid verboden eigenrichting', NJB 2009, p. 2006.

89. Zie onder meer HR 22 december I989, NJ I990, 434 (Kempkes/Samson).

9o. Zie Gras, 'De dwangsom als sanctie', a.w., p. 2005, met verwijzing naar L.E.H. Rutten, Eigenrichting (oratie, I96I).

9I. M.B. Beekhoven van den Boezem, De Dwangsom in het Burgerlijk Recht, a.w., p. I55 betoogt vervolgens dat, juist omdat de dwangsom in haar ogen geen punitief karakter mag hebben, een andersluidend oordeel in de bodemprocedure zou moeten leiden tot verval van het recht op verbeurde dwangsommen. 
is de handhavende werking van een rechtsmiddel een meer of minder toevallige bijwerking van het doel om de verstoring van de privaatrechtelijke verhoudingen te herstellen. De door ons beschreven uitzonderingen daarop zijn: de loonsverhoging bij te late betaling van het loon, de absolute nietigheid van een proeftijdbeding, de verplichting tot winstafdracht (al of niet in gevallen van afwezigheid van goede trouw c.q. in geval van moedwillige inbreuk) in het intellectuele eigendomsrecht, artikel 3:194 lid 2 BW, de (verdergaande) aansprakelijkheid van bestuurders op grond van artikel 2:I3 8 en $248 \mathrm{BW}$ voor het niet voldoen aan de administratie- en publicatieplicht en de ge- en verbodsactie (in combinatie met de vaak daaraan verbonden dwangsom).

In de rechtsleer krijgt 'private handhaving' veel belangstelling, maar niet steeds is duidelijk wat met het begrip wordt bedoeld. Terwijl een aantal van de auteurs handhaving en een instrumentele, functionele opvatting van het privaatrecht vereenzelvigen, is dat voor een aantal andere auteurs niet het geval. Bovendien valt op dat handhaving in algemene bewoordingen wordt aangegrepen als een (mogelijk) wenkend perspectief, maar dat de concrete invulling van de nieuwe of vernieuwende handhavingsmethoden veelal beperkt is tot hele concrete, beperkte onderdelen van het vermogensrecht (bijvoorbeeld de schending van persoonlijkheidsrechten). De discussie over handhaving door privaatrecht wordt klaarblijkelijk gemakkelijker gevoerd door de concrete invulling van die handhavingsmethoden in het midden te laten. Wie in de genoemde werken zoekt naar methoden die bestraffen en op die manier een ex-ante preventieve werking hebben, vindt niet meer dan de omstreden 'punitive damages', die door de meeste auteurs met zijden handschoenen worden aangepakt en hooguit als mogelijkheid worden overwogen voor toegespitste gevallen.

Het opgeroepen beeld maakt duidelijk dat privatisten zich niet erg gemakkelijk voelen bij een nieuwe, tot handhaving strekkende inrichting van het privaatrecht. Gewaagde innovaties waarbij de grenzen van het privaatrecht structureel op de proef worden gesteld, zijn er eigenlijk niet. Veeleer worden bestaande rechtsmiddelen van nieuwe glans voorzien of, zoals in het geval van collectieve acties, in een aangepaste vorm gegoten.

\subsection{Twijfels ten aanzien van de effectiviteit en efficiëntie van private handhaving}

De vraag is gerechtvaardigd of het privaatrecht geschikt is voor handhavingsdoeleinden. Het privaatrecht bestaat immers in belangrijke mate uit open normen. Het is een bekend gegeven dat van normen die onvoldoende specifiek zijn, weinig handhavende werking kan uitgaan. De Engelse rechstgeleerde Atiyah lichtte dit punt als volgt toe:

'One of the reasons why fines (etc.) for driving offences are more likely to achieve deterrent effects than tort liability is that the standards of conduct prescribed by criminal law (...) are usually more precise than those laid down by the law of tort. If we are to take deterrence seriously, we must give people detailed guidance as to how 
to behave. (...) The common law of torts does not typically give detailed guidance but only requires people to take reasonable care according to all the circumstances of the situation they are in. (...) the disadvantage of this approach is that many decisions that a particular defendant was negligent do not have much deterrent potential. ${ }^{92}$

Betreft het echter eenduidige en kenbare normen, dan is eerder aanleiding te geloven dat van een sanctie verbonden aan overtreding daadwerkelijk preventieve werking uitgaat. ${ }^{93}$ Het wekt daarom geen verbazing dat, in de hiervoor besproken (uitzonderings)gevallen waarin ons privaatrecht wel handhavende sancties kent, deze sancties doorgaans verbonden zijn aan eenduidige normen. Een voorbeeld is de hiervoor besproken (verdergaande) aansprakelijkheid van bestuurders op grond van artikel 2:138 en $248 \mathrm{BW}$ voor het niet voldoen aan de administratie- en publicatieplicht. Waar twijfelachtig is of de norm 'gij zult zorgvuldig besturen' voldoende richtinggevend is om het gedrag van bestuurders te beïnvloeden, is beter denkbaar dat een bestuurder zijn of haar gedrag afstemt op de concrete norm 'gij zult uiterlijk dertien maanden na het einde van het boekjaar de jaarrekening van de door u bestuurde rechtspersoon publiceren'. Hetzelfde geldt voor de norm dat een proeftijd niet langer dan twee maanden mag zijn.

Verder kan worden gedacht aan normen die beogen onzorgvuldig gedrag met een hogere graad van verwijtbaarheid, zoals opzet, grove schuld of bewuste roekeloosheid, tegen te gaan. ${ }^{94}$ Omdat het gedrag betreft dat berust op een bewuste, daaraan voorafgaande afweging, 95 is denkbaar dat de dreiging van civielrechtelijke aansprakelijkheid daadwerkelijk eraan bijdraagt zulk maatschappelijk onwenselijk gedrag te ontmoedigen. Vandaar dat bijvoorbeeld W. Snijders de in ons privaatrecht op het eerste gezicht vreemd voorkomende regel van artikel 3:I94 lid 2 BW - dat de deelgenoot die een gemeenschappelijk goed opzettelijk verbergt, bestraft met verbeurte van zijn aandeel - op grond van de gestelde effectiviteit van de bedoelde rechtsregel verdedigt:

'Een wapen dat door de deelgenoten zelf rechtstreeks kan worden gehanteerd, is alleen al om die reden effectiever dan dreiging met een strafvervolging waarbij men van inzicht en beleid van het openbaar ministerie afhankelijk is. ${ }^{96}$

Ook ten aanzien van eenduidige en kenbare normen geldt echter, dat private handhaving alleen effectief kan zijn als en wanneer private partijen in staat zijn

92. P. Cane, Atiyah's Accidents, Compensation and the Law, $5^{\mathrm{e}}$ druk, Edinburgh 1993, p. 365 . In dezelfde zin Van Boom, Efficacious Enforcement in Contract and Tort, a.w., p. 43, met verdere verwijzingen in voetnoot I35.

93. Vgl. ook Corstens, 'Civielrechtelijke, administratiefrechtelijke of strafrechtelijke rechtshandhaving', a.w., p. 20, die in dit kader wijst op het belang van een goede voorlichting 'om burgers met de norm vertrouwd te maken'.

94. Zie ook Du Perron, 'Genoegdoening in het civiele aansprakelijkheidsrecht', a.w., p. I43.

95. Zie over de betekenis van opzet voor het aansprakelijkheidsrecht J. Finnis, 'Intention in Tort Law' in D.G. Owen (ed.) Philosophical Foundations of Tort Law, Oxford I995, p. 229-247.

96. W. Snijders, 'Verleden en Toekomst van art. 3:194 lid 2', a.w., p. 367. 
normschendingen te constateren. Anders dan publieke handhavers, hebben private handhavers geen opsporingsapparaat tot hun beschikking. Daarbij komt dat private partijen lang niet altijd over voldoende financiële middelen en expertise beschikken, om het aanwezige bewijsmateriaal te onderzoeken en juist te interpreteren.

Bovendien is het de vraag hoe efficiënt private handhaving is. Schadevergoedingsprocedures, bijvoorbeeld, zijn notoir inefficiënt. De totale kosten van dergelijke procedures - de kosten van advocaten aan beide zijden inbegrepen - overstijgen niet zelden het in de procedure gehaalde resultaat. ${ }^{97}$ In termen van efficiëntie heeft publieke handhaving bovendien als belangrijk voordeel dat de handhaving van normen centraal plaatsvindt. Daardoor wordt de relevante expertise geconcentreerd en worden dubbele investeringen voorkomen. En minstens zo belangrijk is dat controle kan plaatsvinden op de frequentie en omvang van de in het totaal opgelegde sancties. Aldus kan een optimaal handhavingsniveau worden nagestreefd.

In de actuele discussie over de privaatrechtelijke handhaving van het mededingingsrecht spelen aarzelingen over de effectiviteit en de efficiëntie daarvan een belangrijke rol. Zo betoogde Wils, die als jurist in dienst is bij de Europese Commissie, recent:

'(...) public enforcement, through its reliance on state power, benefits from more effective investigative and sanctioning powers. (...) As to the level of the monetary sanctions (fines or damages), public enforcement has the additional advantage of allowing better control in setting the optimal amount of the sanction. (...) Moreover, effective deterrence does not require that each and every violation is detected and punished, but rather that the expected penalty (...) exceeds the expected gains. In any event, if there is a need to increase the existing level of deterrence and punishment, this should be done by strengthening public enforcement, which (...) is the superior instrument as far as the objective of deterrence and punishment is concerned.' ${ }^{98}$

Vergelijkbare aarzelingen gelden ten aanzien van andere, door ons eerder in dit preadvies besproken private handhavingsinstrumenten. Men kan zich bijvoorbeeld met recht afvragen hoe effectief artikel 3:194 lid 2 BW werkelijk is, nu de deelgenoten in een gemeenschap nauwelijks middelen hebben om vast te stellen of aan die

97. Zie onder meer J.S. Kortmann, The Tort Law Industry, a.w., p. 22 met verdere verwijzingen.

98. Wils, 'The Relationship between Public Antitrust Enforcement and Private Actions for Damages', a.w., p. 8-II. 
gemeenschap goederen zijn onttrokken, laat staan dat die onttrekking opzettelijk heeft plaatsgevonden. 99

\subsection{Spanningsveld private handhaving en publieke handhaving}

Als en voor zover de deur wordt opengezet voor private handhaving, gaat dat mogelijk ten koste van de waarborgen die voor de publieke handhaving gelden. Toen Bolt en Lensing in 1993 de Nederlandse Vereniging voor Rechtsvergelijking preadviseerden over de privaatrechtelijke boete, erkenden zij uitdrukkelijk dat de invoering van een dergelijke boete ten koste zou gaan van de strafrechtelijke waarborgen voor de verdachte. In hun ogen moest dat 'dan maar op de koop toe worden genomen'. ${ }^{\text {Ioo }}$ Naar onze mening geeft de benadering van Bolt en Lensing deze waarborgen te gemakkelijk prijs.

In het privaatrechtelijke debat in Nederland ligt momenteel de nadruk op het argument dat het recht moet voorzien in voldoende rechtsmiddelen. Dat zou een rechtvaardiging zijn voor 'punitive damages'. De vraag is echter of 'punitive damages' (afhankelijk van hun concrete invulling) de toetsing aan artikel 6 EVRM doorstaan. Adriaanse, Barkhuysen, Den Houdijker en Zippro, ${ }^{\text {Ior }}$ alsook een van de preadviseurs van Belgische zijde, Cauffmann, ${ }^{102}$ hebben er reeds op gewezen dat de sanctie van 'punitive damages' zeer wel door het Europese Hof voor de Rechten van de Mens kan worden aangemerkt als een 'criminal charge': zij zijn erop gericht de naleving van algemeen geldende normen te verzekeren en zij hebben een afschikkende en bestraffende aard en om van charge te kunnen spreken dient iemands positie wezenlijk aangetast ('substantially affected') te zijn. ${ }^{\text {I03 }}$ Dit betekent dat het opleggen van de boete met bepaalde waarborgen omgeven moet zijn: er moet sprake zijn van toegang tot een onafhankelijke en onpartijdige rechter, van een eerlijke en openbare behan-

99. Vgl. ook L.C.A. Verstappen, 'De notaris en de boedelafwikkeling', WPNR 65I6 (2003), p. 6r: '(...) ik vrees dat deze sanctie in de normale gevallen weinig effectief is.' Zie voor uitspraken waarin een beroep op artikel 3:I94 lid 2 BW werd gehonoreerd Hof Amsterdam 9 september 2004, LJN AS396o, Rb. Haarlem 22 mei 2007, JIN 2007, 293, Rb. Amsterdam 24 oktober 2007, LJN BB7I63, Hof Leeuwarden I6 september 2008, LJN BFin76, Hof Den Bosch 24 maart 2009, LJN BH8I97. Een beroep op ar.t 3:I94 lid 2 BW werd daarentegen afgewezen in Hof Den Bosch 8 maart 2005, LJN AT9883, Hof Den Bosch 23 mei 2006, PJ 2007, 29, Hof Den Bosch 9 januari 2007, LJN BA2873 en Hof Amsterdam 8 maart 2007, LJN BA4043.

Ioo. A.T. Bolt \& J.A.W. Lensing, Privaatrechtelijke boete, Preadvies voor de Nederlandse Vereniging voor Rechtsvergelijking, 1993, p. 83.

Ior. P.C. Adriaanse, T. Barkhuysen, F.M.J. den Houdijker \& E.-J. Zippro, 'Het EVRM-kader voor invoering van punitive damages in mededingingszaken. Europese toestanden in het schadevergoedingsrecht?', NTBR 2008, p. 280 e.v.

I02. C. Cauffmann, 'Naar een punitief Europees verbintenissenrecht?', TvP 2007, p. 799 e.v.

I03. In EHRM 25 oktober 2005, zaaknr. 6889o/or (Blake/Verenigd Koninkrijk) werd niet als 'criminal charge' gezien een contractuele boete. De boete was namelijk een direct gevolg van de contractbreuk. De civielrechtelijke context speelde bij de beoordeling van het EHRM overigens geen beslissende rol. Om die reden is het goed mogelijk dat het EHRM 'punitive damages' onder omstandigheden als 'criminal charge' aanmerkt. Zie Adriaanse, Barkhuysen, Den Houdijker \& Zippro, 'Het EVRM-kader voor invoering van punitive damages in mededingingszaken', a.w., p. 280 e.v. 
deling van de zaak ${ }^{104}$ binnen een redelijke termijn en van volledige rechtsmacht omtrent de vast te stellen feiten en de toepassing van de normen en van de mogelijkheid om de straf te toetsen aan de evenredigheid. Zoals Adriaanse e.a. besluiten:

'Een verschuiving van publiekrecht naar het privaatrecht of een stimulering van private handhavingsacties juist ter aanvulling van een tekort in de publieke handhavingssfeer, met gebruikmaking van een punitieve boetevariant, kan alleen plaatsvinden als terdege rekening wordt gehouden met fundamentele rechtswaarborgen, zoals voortvloeiend uit het EVRM.' ${ }^{\text {I05 }}$

Anderen hebben betoogd dat privaatrechtelijke sancties met een bestraffend karakter niet binnen het bereik van de strafrechtelijke waarborgen van artikel 6 EVRM vallen, omdat die waarborgen alleen zouden zien op strafvervolging van overheidswege. ${ }^{106}$ Zelfs als dat juist is, neemt dat niet weg dat, los van de precieze reikwijdte van het EVRM, de aan dat artikel ten grondslag liggende waarden een meer algemene, normatieve gelding hebben.

Hetzelfde geldt voor het ne bis in idem-beginsel. Het Nederlandse recht kent geen expliciete regel die zich verzet tegen cumulatie van publiekrechtelijke en privaatrechtelijke bestraffing. Dat neemt echter niet weg dat het, los van de precieze reikwijdte van dat beginsel, algemeen als onwenselijk wordt ervaren dat een normschending 'dubbel' zou worden bestraft. ${ }^{107}$ In Devenish Nutrition Ltd $v$ Sanofi-Aventis SA (France) and others stond het Engelse High Court voor de vraag of het ne bis in idembeginsel in de weg stond aan toekenning van 'exemplary damages' aan een benadeelde van een kartelovertreding waarvoor de Europese Commissie de gedaagde reeds had vervolgd. Een verder probleem was gelegen in het feit dat een grote hoeveelheid personen schade had geleden door de kartelovertreding. Als een privaatrechtelijke boete moest worden toegewezen, ten goede van wie zou die boete dan komen? Is het een kwestie van wie het eerst komt, het eerst maalt, of mogen ook later opkomende eisers 'exemplary damages' vorderen? Als iedere benadeelde recht heeft op 'exemplary damages', hoe houdt men dan controle op de uiteindelijke strafmaat? Deze overwegingen overtuigden de Engelse rechter ervan, de vordering tot betaling van 'exemplary damages' af te wijzen:

I04. De overheid en grote ondernemingen onttrekken zich in privaatrechtelijke gedingen juist dikwijls aan de openbaarheid door hun geschil aan arbiters voor te leggen. Zie over de nadelen daarvan C.H. Sieburgh, 'Arbitrage: de desintegrerende werking van geheime private rechtvaardigheid', in: M.W. Hesselink, C.E. du Perron \& A.F. Salomons (red.), Privaatrecht tussen autonomie en solidariteit, Den Haag 2003, p. 26r e.v.

I05. Adriaanse, Barkhuysen, Den Houdijker en Zippro, 'Het EVRM-kader voor invoering van punitive damages in mededingingszaken', a.w., p. 286.

ro6. Zie bijvoorbeeld J. Boot, 'Privaatrecht \& boete', Ars Aequi 2008, p. 205.

107. Zie bijvoorbeeld A.B. Blomberg, 'Cumulatie van sancties', JBplus 200I, I45 ('Een overdaad aan sanctionering is nooit goed') en Adriaanse, Barkhuysen, Den Houdijker en Zippro, 'Het EVRMkader voor invoering van punitive damages in mededingingszaken', a.w., p. 284 ('Wel wordt door de regering aangenomen dat het beginsel van ne bis in idem ook in bredere zin geldt, maar zonder dat duidelijk wordt op grond waarvan en wat de precieze reikwijdte is'). 
'The plea for exemplary damages is at large. As pleaded there is no way of limiting the exemplary damages to avoid the danger of double counting. There is also the serious problem of assessing the damages, and the fact that the claimants are only part of the class affected by the wrongful conduct; not to mention the scale of the fines imposed by the European Commission. These cumulative factors persuade me that the court would not, at trial, award exemplary damages to these claimants. ${ }^{\text {108 }}$

Bovendien kan worden gewezen op het uit het legaliteitsbeginsel voortvloeiende lex certa-beginsel. ${ }^{109}$ Uit zowel artikel I Sr, art. I6 GW als artikel 7, lid I EVRM volgt dat een strafbepaling voldoende bepaald moet zijn om verbindend te kunnen zijn. Zie daarover onder meer Hoge Raad 3I oktober 2000, NJ 200I, I4 (Krulsla), r.o. 3·4:

'In deze voorschriften ligt onder meer het zogenaamde bepaaldheidsgebod besloten. Dit houdt in dat de burger moet kunnen weten ter zake van welke gedragingen hij kan worden gestraft. De rechtszekerheid eist dit. Van de wetgever mag worden verlangd dat hij met het oog daarop op een zo duidelijk mogelijke wijze delicten omschrijft.'

Het belang dat burgers erbij hebben te weten voor welke gedragingen zij kunnen worden gestraft (en hoe), bestaat niet alleen bij strafrechtelijke bestraffing, maar evenzeer bij privaatrechtelijke figuren die als bestraffend kunnen worden aangemerkt. ${ }^{\text {IIo }}$ Het is dan ook onwenselijk om bijvoorbeeld een dwangsom te verbinden aan een onvoldoende specifiek geformuleerd gebod of verbod. Terecht heeft M. Beekhoven van den Boezem ervoor gepleit dat in een dwangsomveroordeling 'zorgvuldig wordt vastgelegd welk gedrag van de veroordeelde precies wordt verlangd'. ${ }^{\text {III }}$

Ten slotte geldt voor het vorderen van strafoplegging dat dit weloverwogen, afgemeten en onbevooroordeeld dient plaats te vinden. ${ }^{\text {II2 }}$ Uitgangspunt van de strafvervolging in ons land is dat zij geschiedt door onafhankelijke instanties. Tegen de beslissing om tot vervolging over te gaan kan de verdachte bezwaar aantekenen, zodat vooraf kan worden getoetst of hij op toereikende gronden in het openbaar zal terechtstaan. ${ }^{\mathrm{II} 3}$ Het uitgangspunt dat de staat een monopolie heeft op de vervolging en bestraffing van zijn burgers, is dan ook bepaald geen loze kreet. Integendeel: dit monopolie is één van de fundamenten van onze rechtsstaat:

Io8. Devenish Nutrition Ltd v Sanofi-Aventis SA (France) and others [2007] EWHC 2394 (Ch), [2008] 2 WLR 637.

I09. Corstens, Het Nederlands strafprocesrecht, a.w., p. 2, I3 e.v.

IIO. P.C. Adriaanse, T. Barkhuysen, F.M.J. den Houdijker \& E.-J. Zippro, 'Het EVRM-kader voor invoering van punitive damages in mededingingszaken', a.w., p. 280, voetnoot 43 ('Bij invoering van de privaatrechtelijke boete zal met deze bepaling echter wel rekening moeten worden gehouden, in die zin dat toekenning hiervan slechts mogelijk is bij overtreding van voldoende nauwkeurig omschreven gedragingen alsmede daarbij behorende boetes').

III. M.B. Beekhoven van den Boezem, De Dwangsom in het Burgerlijk Recht, a.w., p. I34.

II2. Zie bijvoorbeeld G.J.M. Corstens, Waarborgen rondom het vervolgingsbeleid, IJmuiden I974, p. 42.

II3. Art. 250-252 Sv, waarover Corstens, Het Nederlands strafprocesrecht, a.w., p. 540-544. 
'De monopoliepositie van de overheid op de waarheidsvinding is rechtstreeks verbonden met het overheidsmonopolie voor het strafrecht als geheel. De fundamenten daarvan liggen besloten in het publiekrechtelijk karakter van het strafrecht en daarmee in uitgangspunten en beginselen van onze democratische rechtsstaat. Het waarborgen van rechten van de burger en het voorkomen van eigenrichting zijn daarbij van wezenlijk belang.' ${ }^{\text {II } 4}$

Anders dan handhavers in dienst van de overheid, zullen private handhavers bij de beslissing om wel of niet te handhaven primair door eigen motieven worden bewogen. $\mathrm{Al}$ in $\mathrm{de} \mathrm{I} 7^{\mathrm{e}}$ eeuw waarschuwde Groenewegen van der Made voor het gevaar dat burgers 'ex odio et vindictae cupiditate' - uit haat en wraakzucht - punitieve sancties zouden vorderen. ${ }^{\mathrm{II}}$ Dat gevaar was des te groter, omdat de opbrengst van boetes toekwam aan de eiser. Een weloverwogen, afgemeten en onbevooroordeelde beslissing om rechtsmaatregelen te nemen, kon van burgers onderling niet verwacht worden.

Dat gevaar is tegenwoordig niet minder. In de literatuur wordt dan ook terecht onderkend dat bij de toepassing van artikel 3:I94 lid 2 BW - één van de weinige daadwerkelijk bestraffende bepalingen in ons Burgerlijk Wetboek - persoonlijke gevoelens de overhand kunnen krijgen. 'De beschuldiging van bedrog als bedoeld in dat lid is een zware, waarbij gemakkelijk persoonlijke motieven kunnen zijn betrokken', aldus W. Snijders. ${ }^{\text {II6 }}$ Dat geldt eens te meer waar de partij die de beschuldiging uit - hier: een deelgenoot in de gemeenschap - er zelf financieel beter van wordt als de beschuldiging gegrond blijkt te zijn.

Vergelijkbare bezwaren kleven aan de belangrijkste sanctie in ons burgerlijk procesrecht: de privaatrechtelijke dwangsom. Het gegeven dat de dwangsom aan de eisende partij wordt toegekend, wordt buiten de Benelux onder meer bekritiseerd wegens de private motieven die bij de handhaving van de dwangsomveroordeling kunnen spelen. De Duitser Remien vatte de internationale kritiek pakkend samen:

'Diese ungerechtfertigte Bereicherung sei ein Geschenk für den Sieger des Prozesses, ja sie sei anstößig; dem Gläubiger das Zwangsgeld zukommen zu lassen, heiße, seine Rachedurst oder seine Vergeltungslust zu befriedigen. Vor Gericht zu klagen könne gar ein sehr einträgliches Geschäft werden, ja, der Gläubiger könne womöglich verleitet werden, die Naturalerfüllung nur deshalb zu verlangen, weil er auf den Ertrag des Zwangsgeldes hoffe: Die astreinte werde für ihn so möglicherweise zum Huhn, das goldene Eier legt.' ${ }^{117}$

II4. C.P.M. Cleiren, 'Het monopolie op strafrechtelijke waarheidsvinding', Strafblad 2008, p. 275.

II5. S. Groenewegen van der Made, Tractatus de Legibus Abrogatis et Inusitatis in Hollandia Vicinisque Regionibus, Vol. IV, $3^{\text {rd }}$ ed., I669, ad C. 9.I.2. Zie ook A. Matthaeus, De Criminibus, Vol. IV I644, ad D. 48.20.2.

II6. W. Snijders, 'Verleden en Toekomst van art. 3:194 lid 2' a.w., p. 362.

II7. O.R.M. Remien, Rechtsverwirklichung durch Zwangsgeld, Tübingen 1992, p. I97, met uitgebreide verwijzingen in de voetnoten. 


\subsection{Evaluatie van handhavende rechtsmiddelen}

In dit preadvies hebben wij onderzocht in hoeverre het privaatrecht rechtsmiddelen kent die bijdragen aan de handhaving van normen die het individuele belang van private partijen overstijgen. Het begrip handhaving hebben wij beperkt opgevat, namelijk als het voorkomen van normschendend gedrag door de burger aan te sporen daarvan af te zien. Dat kan door gebruik te maken van rechtsmiddelen die de normschender ofwel een nadeel toebrengen ofwel een door de schending gerealiseerd voordeel ontnemen. Van rechtsmiddelen met een (min of meer toevallige) handhavende werking onderscheiden wij rechtsmiddelen die een handhavende functie hebben.

Tegen de achtergrond van het hiervoor betoogde, is er onzes inziens weinig reden om het privaatrecht als zodanig een handhavende functie toe te kennen. Wij zijn dan ook geen voorstanders van het introduceren van nieuwe handhavende rechtsmiddelen in het privaatrecht die niet passen in het privaatrechtelijke systeem.

Daarmee is echter geenszins gezegd dat de handhavende werking die het privaatrecht in bepaalde opzichten heeft, niet beter zou kunnen worden benut. Daar waar privaatrechtelijke rechtsregels als neveneffect hebben dat zij normschendingen ontmoedigen, is dat neveneffect vanzelfsprekend welkom. Er is onzes inziens daarom niets tegen, om de handhavende werking van privaatrechtelijke rechtsregels nader onder de aandacht te brengen en, waar dat mogelijk is zonder de primaire functie van die regels geweld aan te doen, de handhavende werking te bevorderen. Anders gezegd: wij zien geen hoofdrol, maar wel degelijk een ondersteunende rol voor het privaatrecht als het om handhaving van (het privaatrecht ontstijgende) rechtsnormen gaat.

Hieronder lichten wij ten aanzien van de door ons besproken deelgebieden van het vermogensrecht toe in hoeverre de relevante rechtsregels zich onzes inziens niet verdragen met het door ons gekozen uitgangspunt of in hoeverre zij op een ruimere en/of andere manier inzetbaar zijn.

\subsubsection{Onrechtmatige daad}

Voor het algemene aansprakelijkheidsrecht geldt dat de mate waarin de schadevergoedingsverplichting een ontmoedigende werking kan hebben, afhangt van de duidelijkheid en de kenbaarheid van de geschonden norm. Op een nog niet uitgekristalliseerde, na de gedraging in te vullen open norm, kan niemand zijn gedrag afstemmen. Daarom zijn wij het graag met Van Boom eens dat de handhavende wer- 
king van het privaatrecht gebaat zou zijn bij het zoveel mogelijk stellen van duidelijke regels in plaats van open normen te hanteren. ${ }^{\mathrm{I} 8}$

\section{Persoonlijkheidsrechten en immateriële belangen}

Wat betreft de persoonlijkheidsrechten en immateriële belangen onderkennen wij het belang van de privaatrechtelijke rechtsmiddelen ter ondersteuning van de handhaving van de norm. In de rechtsleer wordt dikwijls ofwel beargumenteerd ofwel voetstoots aangenomen dat de vergoeding van het 'andere nadeel' die de schending van een persoonlijkheidsrecht inhoudt c.q. veroorzaakt, niet anders te verklaren is dan met de, op bestraffing teruggaande, handhavingsgedachte.

Wij hebben hierboven onder 2.I.I reeds toegelicht dat vergoeding van immateriële schade waarvan de vermogensrechtelijke omvang niet (goed) vaststelbaar is, toch compensatoir kan zijn. De vergoeding van schade die geleden is maar waarvan de omvang niet (precies) vaststelbaar is, is in ons recht in het algemeen aanvaard waar het de berekening van schade in abstracto mogelijk maakt indien de omvang van de schade niet kan worden vastgesteld (art. 6:97 BW). Ten aanzien van de reeds staande praktijk om immateriële schade te vergoeden, zijn wij dan ook van mening dat dit een vorm van abstracte berekening van schade is en niet een vorm van punitieve schadevergoeding. Dit houdt in dat indien de benadeelde niet kan aantonen dat hij schade heeft geleden als gevolg van de schending van zijn persoonlijkheidsrecht of andere immateriële belang, hij onzes inziens géén schadevergoeding zou moeten kunnen vorderen. In die gevallen zal de onderliggende norm in beginsel gehandhaafd moeten worden met behulp van het publieke recht.

Daarnaast zien wij echter een ruimere rol weggelegd voor de figuur van de winstafdracht of 'voordeelsafgifte'.

\section{Winstafdracht/voordeelsafgifte}

Waar de schadevergoedingsplicht wellicht te weinig bijdraagt aan de handhaving van persoonlijkheidsrechten, biedt het leerstuk van de voordeelsafgifte mogelijk uitkomst.

Zoals wij hiervoor hebben uiteengezet, is de figuur van de winstafdracht, zoals neergelegd voor ons gemene verbintenissenrecht in artikel 6:104 BW, niet meer dan een wijze van schadebegroting. Wij zouden evenwel menen dat een 'echt' recht op afgifte van voordelen wel degelijk in ons huidige privaatrecht in te bedden zou zijn. Een dergelijk recht zou kunnen voortvloeien uit breder in ons privaatrecht aan-

II8. Dit houdt overigens niet in dat wij in het algemeen, dus buiten het handhavingsvraagstuk, pleiten voor het afschaffen van het gebruik van open normen in het privaatrecht. De schadevergoedingsverplichting die voortvloeit uit de schending van zo'n open norm heeft namelijk een compensatoire werking die van groot belang is en blijft. 
wezige verrijkingsgedachte. ${ }^{\mathrm{II} 9}$ De invalshoek die Linssen heeft gekozen voor het leerstuk van de winstafdracht, is wat ons betreft een goed startpunt. Linssen spreekt van 'voordeelsafgifte', en stelt dat er een 'van het schadevergoedingsrecht volledig ontkoppelde verrijkingsrechtelijke verplichting tot voordeelsafgifte' zou moeten zijn. Deze verrijkingsrechtelijke verplichting moet men zien als een evenknie van de revindicatie en de bezitsactie. ${ }^{\mathrm{I} 20}$ De verplichting tot winstafdracht ligt aldus in het verlengde van de exclusieve bevoegdheid van de benadeelde tot gebruik en uitoefening van zijn recht, waaronder tevens vallen de gerechtigdheid ten aanzien van de voordelen. Door het persoonlijkheidsrecht of immateriële belang op vergelijkbare wijze te behandelen als intellectuele eigendomsrechten, kan de rechthebbende ten aanzien van deze rechten een exclusieve gebruiksbevoegdheid hebben. Dat brengt mee dat hij met uitsluiting van anderen bevoegd is dat recht te gebruiken, uit te oefenen of te exploiteren. Het sluitstuk zou zijn dat bijvoorbeeld de boulevardpers in voorkomende gevallen zou kunnen worden verplicht tot afgifte van voordelen die hij door inbreuk op een persoonlijkheidsrecht genereerde. In deze opvatting wordt het af te geven voordeel niet verminderd met kosten van de door de dader gedane investeringen.

Het betoog van Linssen spreekt ons aan. De introductie van deze vorm van voordeelsafgifte biedt de mogelijkheid daarvan een ruimer gebruik te maken dan thans het geval is. Wel moet daarmee behoedzaam worden omgegaan. Het voordeel is immers door de dader zelf gegenereerd met - afgezien van het geschonden persoonlijkheidsrecht of immateriële belang - eigen middelen. Daarom zouden wij de verplichting willen beperken tot normschenders die niet te goeder trouw het persoonlijkheidsrecht of het immateriële belang schenden. Het aanknopingspunt daarvoor is te vinden in de artikel 3:I20 en I2I BW, die onderscheiden tussen de bezitter te goeder te trouw en de bezitter niet te goeder trouw. De bezitter die niet te goeder trouw is dient de afgescheiden natuurlijke en opeisbaar geworden vruchten af te geven aan de rechthebbende. Aan de bezitter te goeder trouw behoren de afgescheiden natuurlijke en opeisbaar geworden burgerlijke vruchten toe. Analoog hieraan pleiten wij ervoor alleen de dader die niet te goeder trouw het persoonlijkheidsrecht of het immateriële belang van de benadeelde schendt en daarvan voordelen geniet,

II9. Vgl. A.G. Strikwerda, Conclusie voor HR 9 november I990, NJ I99I,I69 (Du Pont/The Globe Manufacturing Company), alinea 34: 'Zowel vereenvoudiging van de bewijspositie van de octrooihouder, als ongedaanmaking van de verrijking van de inbreukmaker (inbreuk mag niet lonen) vormen dus de ratio van de regeling van art. 43 lid 3 Row.'

I20. Linssen, Voordeelsafgifte en ongerechtvaardigde verrijking, a.w., p. 306-307, 599 e.v, 652. Verheij, Vergoeding van immateriële schade wegens aantasting in de persoon, a.w., ziet als een van de gezichtspunten om te bepalen of de door hem gepostuleerde handhavingsfunctie recht geeft op vergoeding van immateriële schade de mate waarin de inbreukmaker (financieel) voordeel heeft van zijn inbreuk. In zijn uitwerking van dit gezichtspunt refereert ook hij aan de bezitsactie en onderscheidt hij, verwijzend naar art. 3:I20 en 3:I2I tussen de inbreukmaker te goeder en niet te goeder trouw. 
tot afgifte van de voordelen te verplichten. ${ }^{\mathrm{I} I \mathrm{I}}$ Vergelijkbaar hiermee is dat de verplichting in het merkenrecht is beperkt tot moedwillige inbreuk.

Duidelijk is dat deze benadering een deel van de gevallen dat nu onder het regime van artikel 6:Io6 lid I onder b BW jo. artikel 95 BW valt, aan dat regime onttrekt op een wijze die goed past in het privaatrechtelijke systeem. Het voordeel is dat de frictie met de primair compensatoire functie van het schadevergoedingsrecht wordt vermeden en dat in geval van schending van een persoonlijkheidsrecht een herstel plaatsvindt op grond van een objectieve maatstaf.

\subsubsection{Overeenkomstenrecht}

\section{Bestraffende loonsverhoging}

Het doel de werkgever te bestraffen in een geval hij te laat het in geld verschuldigde loon aan de werknemer voldoet, is onzes inziens een uitzonderingsgeval in het overeenkomstenrecht. Dat moet ook zo blijven. Buiten het hybride veld van de arbeidsovereenkomst, is het in het privaatrechtelijke overeenkomstenrecht (afgezien van het op grond van wilsovereenstemming overeen te komen boetebeding) geen grond voor het wettelijk opleggen van een boete aan een partij die haar prestatie niet of te laat nakomt.

\section{Nietigheden}

De mogelijkheid om de handhaving van een gedragsnorm of een regel te ondersteunen door een beding in een overeenkomst nietig te achten (en dus niet partieel nietig of voor conversie vatbaar), biedt naar onze mening nuttige mogelijkheden (zoals reeds het geval is voor het proeftijdbeding, het overwerkbeding en de particuliere borgtocht). De gedachte om nietigheden in alle gevallen zoveel mogelijk te relativeren, verdient dan ook geen navolging. Er resteert onzes inziens na het vaststellen van de nietigheid van een reeds uitgevoerde overeenkomst meer dan alleen 'de rechtvaardigheid tussen partijen'. ${ }^{122}$ Het hangt steeds af van de voor het geval relevante omstandigheden of de nietigheid kan bijdragen aan de handhaving.

Ook ten aanzien van andere bedingen dan die in een arbeidsovereenkomst waarvan de wettelijke regeling een beschermende werking heeft, biedt de benadering die partiële nietigheid en conversie van het desbetreffende beding niet toelaat onzes inziens goede en privaatrechtelijk inpasbare mogelijkheden ter handhaving van de norm. Wat betreft het beding dat alle aansprakelijkheid tracht uit te sluiten, is het lastig om de relevante omstandigheden in abstracto af te wegen. In de prak-

\footnotetext{
I2I. Vergelijk voor de ongedaanmakingsvordering (art. 6:203 jo.) art. 6:206 BW. Daarin is geregeld dat wat betreft de ongedaanmaking op de afgifte van vruchten (en de vergoeding van kosten en schade) onder meer art. 3:I20 en I2I BW van overeenkomstige toepassing zijn.

I22. Anders Hijma, Nietigheid en vernietigbaarheid van rechtshandelingen, a.w., p. 96.
} 
tijk worden deze bedingen veelal achteloos en zonder bijbedoelingen opgesteld. In zo'n geval zou het rechtsgevolg van algehele nietigheid van het beding (waardoor de gebruiker van het beding zich op geen enkele beperking van zijn aansprakelijkheid meer kan beroepen) een te zwaar middel zijn. In andere gevallen worden deze bedingen bewust opgesteld en beroept de gebruiker ervan zich erop tegen een onwetende wederpartij. Juist om dit soort praktijken tegen te gaan, verdient het overweging om bij herhaald gebruik van een dergelijk beding door een partij die weet of behoort te weten dat het beding in strijd is met de goede zeden, het beding integraal nietig te achten. Het wordt dan niet gesplitst in een deel dat geldig is (voor zover het vrijtekent voor schade die niet is veroorzaakt door opzettelijk of bewust roekeloos handelen) en een deel dat ongeldig is (voor zover het vrijtekent voor schade die is veroorzaakt door opzettelijk of bewust roekeloos handelen). ${ }^{123}$

\section{Restitutierechtelijke gevolgen van nietigheid}

In het verlengde van het pleidooi voor de ondersteunende rol die nietigheden kunnen spelen bij de handhaving van de gedragsnorm of regel, ligt dat wij pleiten voor een meer geïntegreerde benadering van de nietigheid en haar restitutierechtelijke gevolgen. ${ }^{\mathrm{I} 24}$ Gegeven de mogelijkheid om nietigheden te relativeren, is het wél vaststellen van nietigheid een serieuse aangelegenheid. Juist om die reden is niet goed te begrijpen dat, afgezien van de in artikel 6:2II BW bedoelde gevallen, zonder meer wordt aanvaard dat de ongedaanmaking het met de nietigheid nagestreefde doel ondermijnt.

Een gemeente komt in strijd met de wet op de Ruimtelijke Ordening met een projectontwikkelaar overeen tegen welke vergoeding de gemeente exploitatiewerkzaamheden zal verrichten. Nadat de gemeente de werkzaamheden heeft verricht, vraagt zij om betaling. De projectontwikkelaar beroept zich op de nietigheid van het beding wegens strijd met de wet. De exploitatievergunning behoort op een exploitatieverordening te berusten. Aangenomen dat dit beroep slaagt, zal naar geldend recht de projectontwikkelaar de aan hem verrichte prestatie ongedaan moeten maken. Doordat deze prestatie naar haar aard onmogelijk ongedaan gemaakt kan worden, treedt daarvoor een vergoeding in geld in de plaats. De facto krijgt de gemeente voor

I23. Zie ook Asser/Hartkamp 4-II (2005), nr. 49I: 'Tegen een zodanige splitsing (de splitsing van een contractueel beding in een nietig en een geldig gedeelte, JK en CS) kan pleiten dat een contractspartij, met name een gebruiker van algemene voorwaarden of een werkgever in een arbeidsovereenkomst, in de verleiding zou kunnen komen onereuze bedingen in zijn contracten op te nemen, in de veronderstelling dat het beding, indien het in rechte wordt bestreden, langs de weg der partiële nietigheid in dier voege zal worden 'gereduceerd' dat het alsnog in overeenstemming komt met de wettelijke maatstaven.'

I24. Hijma, Nietigheid en vernietigbaarheid van rechtshandelingen, a.w., p. 77 e.v. pleit eveneens voor een op elkaar betrokken beoordeling (een 'totaalbeslissing') van de nietigheid en de ongedaanmaking. In lijn met de door ons niet gedeelde visie van Hijma dat de nietigheidssanctie alleen in uitzonderingsgevallen van strijd met de wet, de goede zeden en de openbare orde moet worden toegepast, ligt zijn opvatting dat de gevolgen van een eenmaal vastgestelde nietigheid met 'tolerantie' tegemoet getreden moeten worden. 
haar prestatie dus een bedrag dat benadert hetgeen zij op grond van de nietige overeenkomst had bedongen. De praktische betekenis is dat mocht de schending van de wet door de gemeente haar niet baten, zij haar ook niet schaadt.

Een benadering volgens welke de rechter in meer gevallen dan bestreken door artikel 6:2II BW partijen laat in de toestand als waarin hij hen aantreft, heeft als nadeel dat zij willekeurig werkt. De ene keer heeft de projectontwikkelaar reeds betaald en beroept de Gemeente zich op nietigheid, een volgende keer is het andersom. Indien men het verband tussen de nietigheid en de restitutierechtelijke gevolgen structureel zou willen onderstrepen, dient daarvoor een beoordelingskader te bestaan. Van belang daarvoor zijn bijvoorbeeld de hoedanigheid van een partij, haar kennis omtrent de (wettelijke) vereisten, haar bedoeling om de (wettelijke) vereisten te schenden, de mate waarin de schending ingrijpt in algemene belangen, de mate waarin die algemene belangen op een andere wijze worden beschermd (met strafrechtelijke of administratiefrechtelijke sancties). In dit verband verwijzen wij naar de regeling in de PECL. Een vergelijking daarvan met het Nederlandse recht maakt duidelijk dat de regelingen in de PECL wat betreft de aan ongeldigheid van de overeenkomst te verbinden restitutierechtelijke gevolgen in een meer flexibel systeem voorzien dan het Nederlandse recht. Waar naar Nederlands recht slechts in extreme gevallen ongedaanmaking geweigerd kan worden (art. 6:2 lid 2 BW of art. 6:2II BW), geven de PECL daarvoor meer aanknopingspunten. Hierdoor is het mogelijk om in gevallen waarin het (on)geldigheidsoordeel niet zonder meer leidt tot een restitutierechtelijk resultaat dat in lijn is met de achterliggende overwegingen ten aanzien van de geldigheid, bij de ongedaanmaking daarmee toch rekening te houden. Als bijvoorbeeld tussen twee partijen in strijd met de wet een overeenkomst tot stand komt, waarbij een van deze partijen opzettelijk handelde, kan ten aanzien van deze partij de ongedaanmakingsvordering geweigerd worden.

Hoewel bij de regeling in de PECL kanttekeningen zijn te plaatsen, ${ }^{25}$ is de geïntegreerde benadering van ongeldigheid en ongedaanmaking een waardevolle bijdrage aan de rechtsontwikkeling. Juist de leerstukken van de ongeldigheid wegens strijd met de wet, de goede zeden en de openbare orde en van de daarop volgende ongedaanmaking lenen zich niet goed voor een benadering vanuit een vaste hoofdregel. De PECL bieden de mogelijkheid op grond van alle relevante gezichtspunten ten aanzien van beide aspecten tot een geïntegreerd oordeel te komen. ${ }^{\mathrm{I} 26}$ Dit is voor de ondersteunende rol van de nietigheden bij de handhaving van gedragsnormen

I25. Kritisch over de overmaat aan flexibiliteit en de daaraan gerelateerde omvangrijke vrijheid voor de rechter en rechtsonzekerheid is Van Schaick, Principles of European Contract Law (part III) and Dutch Law, a.w., p. 243, 251.256. Kritisch over de benadering van de ongedaanmaking is Van Kooten, Restitutierechtelijke gevolgen van ongeoorloofde overeenkomsten, a.w., p. 315 e.v. die er de voorkeur aan zou hebben gegeven art. 15:I04 lid 2 PECL te redigeren als een uitzondering op de hoofdregel van restitutie en bovendien die uitzondering, conform art. 6:2II BW, in minder gevallen van toepassing te laten zijn.

I26. Zie Sieburgh, Tertium datur, a.w., p. 33-36 en 'The Principle of Social Conformity', in Boele-Woelki \& Grosheide (ed.), Future of European Contract Law (Bundel-Hondius), p. I28-I29. 
en regels van belang, omdat deze werking een van de omstandigheden kan zijn op grond waarvan een uiteindelijk oordeel wordt gevormd.

Stap naar de geïntegreerde benadering: ongedaanmaking in strijd met de redelijkheid en billijkheid

Om de nietigheid en daaropvolgende ongedaanmaking in staat te stellen ondersteuning te verlenen aan de strekking van de regel wiens schending tot de nietigheid leidt, zouden wij de mogelijkheid om ongedaanmaking in strijd te achten met de redelijkheid en billijkheid willen invullen met eerder genoemde aanknopingspunten. ${ }^{127}$

Voor het geval van de gemeente en de projectontwikkelaar geldt dat de gemeente in strijd met het publieke recht het privaatrecht inzet om een vergoeding te bedingen voor de door haar te verrichten exploitatiewerkzaamheden. Het is merkwaardig dat de in Nederland gekozen privaatrechtelijke oplossing (de overeenkomst is nietig en partijen moeten wederzijds ongedaan maken) de reden van de nietigheid niet weerspiegelt. Die is namelijk daarin gelegen dat een overheid het publieke recht niet onaanvaardbaar mag doorkruisen door gebruik te maken van een privaatrechtelijke weg als er een geschikte publiekrechtelijke weg voorhanden is. Het privaatrechtelijke oordeel bekrachtigt echter (de facto) de doorkruisende handelwijze van de gemeente. Onzes inziens is dit een goed voorbeeld van een geval waarin degene die de ongedaanmaking vordert (de gemeente) deze vordering kan worden geweigerd. De aanknopingspunten daarvoor zijn de hoedanigheid van de gemeente, het feit dat de gemeente de publiekrechtelijke regel kent of behoort te kennen en het feit dat het algemene belang er mee is gebaat als de overheid zich houdt aan publiekrechtelijke regels die ter bescherming van burgers zijn opgesteld. De terugvordering door de Gemeente is op grond daarvan in strijd met de redelijkheid en billijkheid (art. 6:2 lid 2 BW en art. 6:248 lid 2 BW).

Deze benadering houdt in dat de projectontwikkelaar de prestatie mag behouden, zonder daarvoor een wederprestatie te verrichten. In het geval de projectontwikkelaar reeds betaald zou hebben, heeft hij een ongedaanmakingsvordering. Men zou kunnen menen dat dit resultaat leidt tot een verrijking van de projectontwikkelaar c.q. burger. Onzes inziens betreft het echter een verrijking die haar grond vindt in het wettelijk systeem, in het bijzonder de samenhang tussen publiekrechtelijke normen en de daaraan te verbinden privaatrechtelijke rechtsgevolgen. Nu wettelijk is geregeld dat de gemeente de privaatrechtelijk bedongen vergoeding niet mocht bedingen, ontvalt aan de vergoeding de grondslag, niet aan de door de gemeente

I27. Vgl. de reeds aangehaalde overweging in HR 28 juni I99I, NJ I992, 787 (Verkerk/Van der Veen q.q.): 'Wel kan zich het geval voordoen dat toewijzing van een zodanige vordering - in de bewoordingen van art. 6:2 lid $2 \mathrm{BW}$ - in de gegeven omstandigheden naar maatstaven van redelijkheid en billijkheid onaanvaardbaar zou zijn (Parlementaire Geschiedenis Boek 3, Inv. 3, 5 en 6, p. II68-Ii69, telkens punt a), (...).' 
toegezegde tegenprestatie. De gemeente werd niet gedwongen om de prestatie te verrichten. Op een gebrekkige wil van de gemeente kan de ongerechtvaardigdheid van de verrijking dus evenmin worden gebaseerd. Al met al wordt een positieve prikkel om de wet te schenden (het valt altijd te proberen om met een privaatrechtelijke overeenkomst de publiekrechtelijke waarborgen te omzeilen en een hogere exploitatievergoeding te krijgen) weggenomen.

Voordeelsafgifte of winstafdracht bij opzettelijke wanprestatie

Op dezelfde gronden als aangevoerd voor de voordeelsafgifte in geval van schending van persoonlijkheidsrechten en immateriële belangen en winstafdracht in het aansprakelijkheidsrecht en (hierna) in het intellectuele eigendomsrecht, zien wij goede mogelijkheden om in geval van afwezigheid van goede trouw c.q. bij aanwezigheid van opzet of grove schuld aan de zijde van de wanpresterende partij ten aanzien van de niet-nakoming, een vordering tot afgifte van daardoor genoten voordeel of afdracht van daardoor gegenereerde winst toe te wijzen. De vordering berust op de gedachte dat de dader een aan de benadeelde toekomend recht ten onrechte inzet ter verkrijging van voordelen en aldus wordt verrijkt. De vordering is derhalve niet gekoppeld aan de door de wederpartij geleden schade. Deze benadering biedt een goede mogelijkheid om de gedragsnorm te ondersteunen dat men een eenmaal gemaakte afspraak moet nakomen.

\subsubsection{Intellectueel eigendomsrecht}

In lijn met ons standpunt om in het algemene aansprakelijkheid een 'echt' recht op winstafdracht te introduceren voor gevallen waarin de dader niet te goeder trouw is, pleiten wij voor een mutatis mutandis eenzelfde aanpak voor het intellectuele eigendomsrecht. Buiten gevallen van afwezigheid van goede trouw zien wij onvoldoende rechtvaardiging voor een 'echt' recht op winstafdracht. Bovendien is het twijfelachtig of de ontmoedigende werking die in gevallen van afwezigheid van goede trouw van de winstafdracht kan uitgaan, zich in gevallen van een louter nalatige inbreuk doet gelden. Hetzelfde is betoogd door Deurvorst, die daarin werd bijgevallen door Quaedvlieg:

'(...) de in het begrip schuld in de zin van nalatigheid of onachtzaamheid (negatief handelen) begrepen gemoedstoestanden zijn niet als dergelijke prikkels tot positief handelen te beschouwen. De toewijzing van winstafdracht dient daarom beperkt te blijven tot gevallen van ernstige inbreuk zoals piraterij of flagrante inbreuk, in welke gevallen opzet kenmerkend is.' ${ }^{2} 28$

I28. T.E. Deurvorst, Schadevergoeding, voldoening van een redelijke gebruiksvergoeding en winstafdracht bij inbreuk op intellectuele eigendomsrechten, Deventer 1994, p. I74. Vgl. de boekbespreking door A.A. Quaedvlieg in RM Themis I997, p. 73, 1.k. 


\subsubsection{Goederen- en faillissementsrecht}

Voorts zetten wij vraagtekens bij het bestaansrecht van de rechtsregel van artikel 3:I94 lid 2 BW, dat opzettelijke verzwijging van een gemeenschappelijk goed door een deelgenoot bestraft met verbeurte van zijn aandeel. Mogelijk is artikel 3:I94 lid 2 BW een effectief handhavingsinstrument, maar dat alleen vormt onvoldoende rechtvaardiging voor een dergelijke rechtsregel. Wij zouden daarover anders denken, als artikel 3:I94 lid 2 BW het enig denkbare handhavingsinstrument zou zijn, zoals W. Snijders lijkt te suggereren:

'Zonder een regel als (de regel van 3:I94 lid 2 BW) is aan verzwijging nauwelijks enig risico verbonden; het enige gevaar dat men loopt, is dat het verzwegene alsnog in de verdeling moet worden betrokken, hoogstens met vergoeding van enige schade ter zake van vertraging.' ${ }^{129}$

Onzes inziens gaat Snijders daarmee echter voorbij aan het feit dat het opzettelijk verzwijgen van een gemeenschappelijk goed strafrechtelijk als 'verduistering' wordt gekwalificeerd, dat kan worden bestraft met maximaal drie jaren gevangenisstraf of een geldboete van $€ 74.000 .{ }^{130}$ Voor de deelgenoot die tevens executeur-testamentair is, geldt het hogere maximum van vijf jaren gevangenisstraf. ${ }^{1{ }^{1} \mathrm{I}}$ Dat de bedriegende deelgenoot geen ander risico zou lopen dan dat hij het verzwegen goed in de gemeenschap moet terugbrengen, is daarom onjuist.

Een beroep op artikel 3:194 lid 2 BW - en daarmee de (zware) beschuldiging van een opzettelijk verborgen houden van een gemeenschappelijk goed - zal moeten komen van de zijde van de overige deelgenoten. Zij hebben daarbij een evident economisch belang: als de beschuldiging gegrond wordt bevonden, wast het verbeurde aandeel aan bij hun eigen aandelen in de gemeenschap. Daarbij komt dat het artikel bij uitstek relevant zal zijn in situaties waarin de emoties van partijen hoog op kunnen lopen: de verdeling van een nalatenschap, de ontbonden huwelijksgemeenschap, de ontbonden maatschap, etc. In dergelijke situaties is het risico verhoogd dat bij de afweging of het wenselijk is een deelgenoot te beschuldigen van verzwijging - en daarmee de facto te vervolgen voor verduistering - oneigenlijke argumenten de overhand voeren.

Daarbij komt dat moeilijk is in te zien waarom verduistering door een deelgenoot zodanig zou verschillen van andere vormen van verduistering, dat het de uitzonderlijke rechtsregel van artikel 3:194 lid 2 BW rechtvaardigt. Hoewel Snijders terecht wijst op het grote gemak waarmee een deelgenoot het bestaan van een

I29. W. Snijders, 'Verleden en Toekomst van art. 3:I94 lid 2', a.w., p. 36I.

I30. Art. 32I Sr ('Hij die opzettelijk enig goed dat geheel of ten dele aan een ander toebehoort en dat hij anders dan door misdrijf onder zich heeft, wederrechtelijk zich toeëigent, wordt, als schuldig aan verduistering, gestraft met gevangenisstraf van ten hoogste drie jaren of geldboete van de vijfde categorie.' (curs. JK en CS).

I3I. Art. 323 Sr. 
gemeenschappelijk goed verborgen kan houden, geldt hetzelfde voor vele andere verschijningsvormen van verduistering. Wat bijvoorbeeld te denken van de als executeur-testamentair fungerende derde, die zich een groot bedrag op de spaarrekening van de erflater toeëigent? Of van iemand die stelselmatig waardevolle zaken van zijn dementerende buurman leent, om deze vervolgens nimmer te retourneren? Bovendien geldt ook voor andere vergrijpen dan verduistering dat het plegen ervan betrekkelijk eenvoudig is (en de pakkans gering).

Schoordijk heeft terecht de vraag gesteld of het bestraffende karakter van artikel 3:I94 lid 2 BW 'niet wijst op een denken, dat niet meer van onze tijd is'. ${ }^{132}$ In navolging van Schoordijk zouden wij menen dat de strafbepaling van artikel 3:194 lid 2 BW niet goed past in ons huidige privaatrecht. Nu tenminste twijfelachtig is of de privaatrechtelijke handhaving op dit punt effectief is en het strafrecht bovendien reeds in een sanctie voorziet, zouden wij willen aanbevelen om artikel 3:I94 lid 2 BW te schrappen.

\subsubsection{Dwangsom}

Het komt ons voor dat de wijd verbreide opvatting dat de dwangsom geen bestraffend karakter heeft, vooral is ingegeven door het besef dat als de dwangsom wel een 'straf' zou zijn, vraagtekens gezet moeten worden bij het huidige niveau van de waarborgen voor de veroordeelde. 'Het behoeft geen betoog dat de civielrechtelijke procedure, waarin een dwangsomveroordeling wordt uitgesproken, in het licht van deze strafrechtelijke beginselen niet door de beugel kan', aldus M. Beekhoven van den Boezem. ${ }^{33}$ Echter, ook als we ervan zouden uitgaan dat de dwangsom in strikt juridische zin niet als een 'straf' moet worden gekwalificeerd, geldt dat verscheidene observaties die wij in het voorgaande hoofdstuk hebben gemaakt van belang blijven.

Dit geldt in de eerste plaats voor de effectiviteit van de privaatrechtelijke handhaving. Zoals wij hebben opgemerkt, is de aanwezigheid van een daadwerkelijk preventieve werking bij eenduidige en kenbare normen waarschijnlijker dan bij vage of open normen. Bovendien is het - ook zonder directe toepasselijkheid van het strafrechtelijke lex certa-beginsel - onredelijk om een dwangsom te verbinden aan een in algemene termen geformuleerd verbod of gebod. De gedaagde die op straffe van een dwangsom veroordeeld is iets te doen of na te laten, moet zonder noemenswaardige inspanning kunnen vaststellen wat er precies van hem wordt verwacht. Onzes inziens is bijvoorbeeld een gebod tot 'nakoming' van een complexe overeenkomst - zonder dat daarbij nader wordt gespecificeerd welke verplichtingen daaruit voor de gedaagde voortvloeien - te weinig specifiek om te worden neergelegd in een dwangsomveroordeling.

I32. H.C.F. Schoordijk, Mede-Eigendom, Gemeenschap, Rechtspersoonlijkheid, Deventer I983, p. I50.

I33. M.B. Beekhoven van den Boezem, De Dwangsom in het Burgerlijk Recht, a.w., p. 66. 
In de Nederlandse rechtspraktijk zijn dergelijke, in algemene bewoordingen gestelde dwangsomveroordelingen evenwel aan de orde van de dag. De Hoge Raad laat daarvoor ook bewust ruimte. Zou bijvoorbeeld in het geval van een complexe overeenkomst een hoge mate van precisering vereist zijn, dan kan dat aanleiding zijn voor herhaalde korte gedingen tussen dezelfde partijen, waarin telkens een gebod tot nakoming van een nieuwe verplichting wordt geëist. Het achterliggende dilemma is treffend samengevat door A-G Vranken in zijn conclusie voor HR 20 mei I994, NJ I994, 652 (Van Weezenbeek/Het Financieele Dagblad), nr. I8:

\begin{abstract}
'Voorop dient te staan dat in beginsel een verbod - of, zoals in het onderhavige geval, een bevel - met zoveel mogelijk precisie omschreven moet worden. Vast staat echter dat dit in een aantal gevallen niet kan. Men kan dan twee wegen volgen. De eerste is dat men toch zoveel mogelijk precisie eist en op voorhand voor lief neemt dat ten aanzien van alle niet door het verbod bestreken gedragingen steeds opnieuw de rechter moet worden ingeschakeld om een verbod af te dwingen. In deze benadering vermijdt men executiegeschillen, maar lokt men nieuwe verbodsprocedures uit. De tweede weg is dat men in algemene termen opgelegde verboden wel accepteert. Dan echter gebeurt het omgekeerde: men vermijdt nieuwe verbodsprocedures, maar de prijs hiervoor is een toename van het aantal executiegeschillen.'
\end{abstract}

De Hoge Raad heeft de tweede weg gekozen. Gevolg is dat het risico van een verkeerde interpretatie van het in algemene termen gesteld ge- of verbod wordt gelegd bij de veroordeelde. Begrijpt hij de veroordeling verkeerd, dan loopt hij het risico ongemerkt dwangsommen te verbeuren. Dit risico wordt door de Hoge Raad onderkend en was de aanleiding om door middel van de zogenoemde Lexington-leer de veroordeelde tegemoet te komen. Ingevolge die leer is van verbeurte van dwangsommen pas sprake als in ernst niet kan worden betwijfeld dat de gewraakte handelingen inbreuken van de dwangsomveroordeling zouden opleveren. ${ }^{134}$

Hoewel de Lexington-leer het hiervoor beschreven risico beperkt, neemt zij het niet weg. Immers, juist omdat een veroordeling in algemene termen is gesteld, kunnen partijen in redelijkheid verschillend denken over de vraag hoe ruim het ge- of verbod is bedoeld. Uit duurovereenkomsten, bijvoorbeeld, vloeit dikwijls een veelheid aan hoofd- en nevenverplichtingen voort. Niet zelden blijkt dat aan specifieke bepalingen in de praktijk door partijen op geheel andere wijze invulling is gegeven. Spreekt nu de rechter een algemeen geformuleerd gebod tot nakoming uit, dan is het voor de veroordeelde lastig in te schatten wat precies van hem wordt verwacht. De eiser, daarentegen, verkeert in de benijdenswaardige positie dat hij zich daarover niet behoeft te bekommeren. Hij kan afwachten wat de gedaagde ter uitvoering van de dwangsomveroordeling presteert, om vervolgens te onderzoeken of hij een niet of niet in alle opzichten nagekomen verplichting kan identificeren waarvan, achteraf bezien (!), kan worden gesteld dat in ernst niet valt te betwijfelen dat zij binnen het

134. Zie onder meer HR 3 januari I964, NJ I964, 445 (Lexington), HR I8 februari I966, NJ I966, 208 (Klokkenspel), HR 5 april 2002, NJ 2003, 356 (Euromedica/Merck). 
bereik van de veroordeling viel. A-G Verkade spreekt in dit kader van een 'onevenwichtigheid' ten nadele van de veroordeelde:

'De vraag of van bepaalde handelingen niet in ernst kan worden betwijfeld dat zij, mede gelet op de gronden waarop het verbod werd gegeven, inbreuken als door de rechter verboden, opleveren, is een vraag waarover redelijk denkende mensen nog steeds van mening kunnen verschillen. (....) De eiser-executant van een veroordelend vonnis kan met nauwelijks meer risico dan het proceskostenrisico trachten de executierechter tot een ruimere lezing te bewegen; voor de veroordeelde speelt daarnaast steeds het - veelal torenhoge, soms zelfs existentie-bedreigende - dwangsommenrisico.' 135

Omdat de dwangsom materieel overeenkomt met een straf, zijn wij van mening dat deze onevenwichtigheid op gespannen voet staat met de gedachte die ten grondslag ligt aan het strafrechtelijke lex certa-beginsel. De gedaagde die veroordeeld is iets te doen of na te laten, moet, voor zover die veroordeling is versterkt met een dwangsom, daaruit eenvoudig kunnen afleiden wat precies van hem wordt verwacht. Anders dan de Hoge Raad zouden wij dan ook de voorkeur geven aan een benadering waarbij in alle gevallen zoveel mogelijk precisie wordt geëist bij de formulering van dwangsomveroordelingen. Dat daarvan in sommige gevallen het gevolg zal zijn dat een eiser zich bij herhaling tot de voorzieningenrechter wendt, moet daarbij op de koop toe worden genomen. Gesteld voor de keuze tussen meer verbodsacties of meer executiegeschillen - of: onevenwichtigheid ten nadele van de eiser of de veroordeelde - zou de bestraffende aard van de dwangsom onzes inziens de doorslag ten gunste van de veroordeelde moeten geven.

In de tweede plaats zijn wij van mening dat het strafkarakter van de dwangsom gevolgen moet hebben, waar een verbod dat met een dwangsom is versterkt materieel overeenkomt met een publiekrechtelijk gesanctioneerd verbod. Het ne bis in idembeginsel van artikel $68 \mathrm{Sr}$ heeft weliswaar formeel geen betekenis voor het leerstuk van de privaatrechtelijke dwangsom. ${ }^{136}$ Dat neemt echter niet weg dat het, los van de precieze reikwijdte van dat beginsel, onwenselijk is dat een normschending 'dubbel' wordt bestraft. Is de norm die de burgerlijke rechter door middel van een dwangsomveroordeling beoogt te handhaven tevens publiekrechtelijk gesanctioneerd, dan dient de reeds bestaande afschrikkende werking van de publiekrechtelijke sancties meegewogen te worden bij de vaststelling van de dwangsom. Andersom dient de bestuursrechter of de strafrechter, in die gevallen waarin een overtreding van een publiekrechtelijke norm reeds heeft geleid tot verbeurte van privaatrechtelijke dwangsommen, zulks mee te wegen bij het bepalen van de publiekrechtelijke sanctie. Vergelijk in dit kader ook Hof Den Haag I juni 2005, waar de invordering van administratiefrechtelijke dwangsommen niet in de weg stond aan strafvervolging

135. Zie de conclusie van A-G Verkade voor HR 5 april 2002, NJ 2006, 55 (Euromedica/Merck II), nr. 6.8.

136. Al was het maar omdat de normschending een andere is: vgl. de conclusie van A-G Knigge voor HR 20 maart 2007, RvdW 2007, 346. 
op basis van hetzelfde feitencomplex, maar het Hof bij het bepalen van de strafmaat de verbeurde dwangsommen vrijwel geheel in mindering lijkt te hebben gebracht. ${ }^{137}$

Ten slotte werpen wij de vraag op of het, tegen de achtergrond van hetgeen wij hiervoor reeds over de dwangsom hebben gezegd, niet de voorkeur verdient om verbeurde dwangsommen te laten toekomen aan de Staat of een ander openbaar fonds. De normovertreding die met de dwangsom wordt gesanctioneerd, heeft een publiek karakter: 'gij zult de rechter gehoorzamen'. Waar het dergelijke publieke rechtsnormen betreft, ligt minder in de rede private partijen financieel voordeel te laten genieten uit handhavingsactiviteiten. Bij de beslissing om dwangsommen te vorderen, zal een private partij zich zelden objectief opstellen. Het is in haar belang om bij de geringste aanwijzing van een overtreding, hoe triviaal ook, betaling van de volledige dwangsom te eisen. 'Niet geschoten is altijd mis.' In het geldende recht doet zich bovendien de eigenaardige situatie voor dat de eiser in een dwangsomprocedure een (soms aanzienlijk) economisch belang heeft bij een overtreding van de dwangsomveroordeling door zijn wederpartij.

Zouden de verbeurde dwangsommen in de staatskas vloeien, dan zouden deze bezwaren zijn weggenomen, zonder dat daarbij wordt afgedaan aan de preventieve werking van de dwangsomveroordeling. Voor uw vereniging is dit geen nieuwe gedachte. $\mathrm{Al}$ in ig6r preadviseerde Van Opstall:

'Beter ware m.i. een regeling krachtens welke de dwangsom verbeurd wordt ten behoeve van de Staat, of, zo deze zelf de veroordeelde mocht zijn, ten behoeve een door de rechter aan te wijzen instelling, die niet is één van de partijen tussen welke het vonnis werd gewezen.' ${ }^{138}$

Een vergelijkbaar systeem vindt men onder meer in Duitsland, Oostenrijk en Engeland. ${ }^{139}$ Dezelfde oplossing werd in I980 voorgestaan door Blaauw en eerder dit jaar door Gras. ${ }^{140}$ Omdat het initiatief tot invordering niettemin aan de wederpartij van de veroordeelde wordt gelaten, is denkbaar dat een dergelijk systeem tot 'minder frisse onderhandelingen' zal leiden. ${ }^{\mathrm{I}}{ }^{\mathrm{I}}$ De druk van verbeurte aan de Staat kan immers gebruikt worden om een gunstige minnelijke regeling af te dwingen. De oplossing van Van Opstall was eenvoudig: 'Bedingen waarbij voor (de kwijtschelding van dwangsommen) een niet reeds uit anderen hoofde (...) verschuldigde prestatie wordt toegezegd, zijn nietig.' ${ }^{\text {I42 }}$ In Duitsland wordt onderkend dat

I37. Hof Den Haag I juni 2005, kenbaar uit HR 20 maart 2007, RvdW 2007, 346.

I38. S.N. van Opstall, De dwangsom in het Nederlandse Recht, Preadvies Vereniging voor de Vergelijkende Studie van het Recht van België en Nederland, Zwolle en Antwerpen I96I, p. I42.

I39. Remien, Rechtsverwirklichung durch Zwangsgeld, a.w., p. I92-I93.

I40. R.M. Blaauw, Executiemiddelen; de sanctionering van vonnissen, veroordelend tot een andere prestatie dan betaling in geld, Preadvies Nederlandse Vereniging voor Rechtsvergelijking, Deventer I980, p. 56-58 en Gras, a.w., NJB 2009, p. 2004-2009.

I4I. Blaauw, Executiemiddelen, a.w., p. 56.

I42. Van Opstall, De dwangsom in het Nederlandse Recht, a.w., p. I59, voetnoot I. Instemmend: Blaauw, Executiemiddelen, a.w., p. 58. 
dwangsomveroordelingen in de praktijk regelmatig worden 'afgekocht', maar dit lijkt daar niet als problematisch te worden ervaren. Immers, dergelijke schikkingen doen niet af aan de preventieve werking van de dwangsomveroordeling, die er bovendien toe heeft bijgedragen dat partijen hun geschil alsnog in der minne hebben kunnen oplossen. ${ }^{\text {I43 }}$

\section{Aanbevelingen}

Tegen het toekennen van een handhavende functie, in de door ons bedoelde (beperkte) zin (zie I.3 en 3.4), aan het privaatrecht zijn belangrijke bezwaren in te brengen. In de eerste plaats is het privaatrecht niet een systeem waarbinnen de handhaving van algemene belangen efficiënt kan plaatsvinden. In de tweede plaats biedt het burgerlijke (proces)recht geen legitimatie voor de middelen waarmee privaatrechtelijk gehandhaafd zou kunnen worden (privaatrechtelijke boetes). $\mathrm{Nu}$ het publiekrechtelijke handhavingssysteem in Nederland goed is georganiseerd, bestaat er geen aanleiding om de handhaving bij het privaatrecht onder te brengen. Ten aanzien van een aantal thans bestaande rechtsmiddelen leidt dit ertoe dat zij zich onzes inziens slecht of niet verdragen met de door ons gekozen uitgangspunten (private straffen (4.I, 4.4 en 4.5)).

Dit neemt niet weg dat privaatrechtelijke rechtsmiddelen een handhavende werking kunnen hebben. Wij pleiten ervoor de ondersteunende rol die het privaatrecht aldus bij de handhaving van algemene belangen kan spelen, zo goed mogelijk te benutten. Wij stellen dan ook voor een aantal rechtsmiddelen op een ruimere en/of andere manier in te zetten (voordeelsafgifte en winstafdracht (4.2) en nietigheid en ongedaanmaking (4.3)).

\section{I Geen 'private straffen'}

Zodra het gebied wordt betreden waarbinnen de ene burger de andere burger bestraft en hij op grond van de onrechtmatige daad van de ander recht heeft op een hogere schadevergoeding dan de door hem geleden (vermogens)schade beloopt, raken we aan het strafrechtelijke legaliteitsbeginsel en mogelijk aan de 'criminal charge' en zijn aanvullende waarborgen vereist. Bovendien staat de gedachte ons tegen dat burgers elkaar kunnen bestraffen en daarbij een financieel voordeel kunnen behalen. De beslissing om bestraffing van een burger na te streven - dat wil zeggen: de burger te vervolgen - dient weloverwogen, afgemeten en onbevooroordeeld plaats te vinden. In ons land is die beslissing, op enkele uitzonderingen na, exclusief in handen van de overheid gegeven. De incidentele onvrede met de wijze waarop de overheid met die verantwoordelijkheid omgaat, zou onzes inziens primair aanleiding moeten zijn om te bezien of het publieke handhavingssysteem heroverweging behoeft. De min of meer impulsieve reactie om gestelde leemtes in het

I43. Remien, Rechtsverwirklichung durch Zwangsgeld, a.w., p.I96-I97. 
publieke handhavingssysteem op te vullen met private handhaving, dient te worden onderdrukt. Om met Lord Rodger of Earlsferry te spreken:

'What seems to me to be unhealthy, however, is that ... civil proceedings are used, not for the true purpose for which they were designed, but rather as a substitute for the criminal proceedings which the prosecuting authorities deliberately declined to bring.' ${ }^{144}$

Daarbij komt dat de effectiviteit en de efficiëntie van private handhaving twijfelachtig is.

\subsection{Verruiming leerstuk voordeelsafgifte en winstafdracht in gemene aansprakelijkheidsrecht}

Wij zien gronden om voordeelsafgifte en winstafdracht en voordeelsafgifte in het gemene aansprakelijkheid ruimer in te zetten. De reden hiervoor is dat degene die een recht (persoonlijkheidsrecht, intellectueel eigendomsrecht, vorderingsrecht) van de benadeelde schendt en daardoor voordelen geniet, door die voordelen wordt verrijkt. Omdat hij ter verwerving van die voordelen (mede) zijn eigen middelen aanwendt, pleiten wij voor beperking van de verplichting tot gevallen waarin de dader niet te goeder trouw is. Daarvan is in ieder geval sprake als hij moedwillig inbreuk maakt, of wanneer hem opzet of grove schuld kan worden verweten bijvoorbeeld ten aanzien van het plegen van wanprestatie. Zowel de verruiming van de mogelijkheid om te verplichten tot afgifte van voordelen of afdracht van winst op grond van de verrijkingsgedachte, als de beperking daarvan tot gevallen van afwezigheid van goede trouw vertonen analogieën met reeds bekende rechtsmiddelen. Te denken valt aan de ongedaanmakingsverplichting ten aanzien van vruchten, die beperkt is tot de ontvanger die niet te goeder trouw is (art. 6:206 jo. art. 3:120 en I2I BW).

\subsection{Flexible inzet van nietigheid en ongedaanmaking}

Wij pleiten voor het inzetten van integrale nietigheid van een beding, indien met het handhaven van de onderliggende norm algemene belangen gebaat zijn. Dit is het geval in het arbeidsrecht. Ook mogelijk is om integrale nietigheid in te zetten in geval de gebruiker van algemene voorwaarden die in strijd zijn met de wet of de goede zeden zich daarvan bewust is of behoort te zijn. De nietigheid kan dan een preventieve werking hebben.

Voorts is het onzes inziens wenselijk om ongedaanmaking af te wijzen (wegens strijd met de redelijkheid en billijkheid) in geval een nietige overeenkomst ten uitvoer is gelegd en het algemeen belang daarmee gediend is. Evenals bij de winstafdracht is de afwezigheid van goede trouw aan de zijde van de partij wie de vordering

I44. A. Rodger, 'The Relationship between Private and Criminal Law - a View from Britain' in A.M. Hol en C.J.J.M. Stolker (eds.) Over de grenzen van strafrecht en burgerlijk recht, Deventer I995 p. II6. 
tot ongedaanmaking wordt ontzegd, van belang. Onzes inziens is geen sprake van een ongerechtvaardigde verrijking aan de zijde van degene die de prestatie mag behouden. De verrijking vindt haar grond in het wettelijk systeem.

Deze oplossing heeft niet tot gevolg dat het privaatrecht wordt gebruikt voor het toevoegen van leed. Veeleer gaat het erom een positieve prikkel om de wet te schenden (het valt altijd te proberen om met een privaatrechtelijke overeenkomst de publiekrechtelijke waarborgen te omzeilen) weg te nemen.

\subsection{Afschaffing artikel 3:194 lid 2 BW}

Wij zetten vraagtekens bij het bestaansrecht van de rechtsregel van artikel 3:194 lid 2 BW, dat opzettelijke verzwijging van een gemeenschappelijk goed door een deelgenoot bestraft met verbeurte van zijn aandeel. Het opzettelijk verzwijgen van een gemeenschappelijk goed wordt strafrechtelijk als 'verduistering' gekwalificeerd. Een beroep op artikel 3:I94 lid 2 BW - en daarmee de (zware) beschuldiging van een strafrechtelijk vergrijp - zal moeten komen van de zijde van de overige deelgenoten. Zij hebben daarbij een evident economisch belang: als de beschuldiging gegrond wordt bevonden, wast het verbeurde aandeel aan bij hun eigen aandelen in de gemeenschap. Daarbij komt dat het artikel bij uitstek relevant zal zijn in situaties waarin de emoties van partijen hoog op kunnen lopen: de verdeling van een nalatenschap, de ontbonden huwelijksgemeenschap, de ontbonden maatschap, enzovoort. In dergelijke situaties is het risico verhoogd dat bij de afweging of het wenselijk is een deelgenoot te beschuldigen van verzwijging - en daarmee de facto te vervolgen voor verduistering - oneigenlijke argumenten de overhand voeren. Wij bevelen aan om artikel 3:194 lid 2 BW te schrappen.

\subsection{Aanpassingen in de regeling van de privaatrechtelijke dwangsom}

De Lexington-leer van de Hoge Raad leidt tot een onevenwichtigheid ten nadele van de veroordeelde in een dwangsomprocedure. Omdat de dwangsom onzes inziens materieel overeenkomt met een straf, zijn wij van mening dat deze onevenwichtigheid op gespannen voet staat met de gedachte die ten grondslag ligt aan het strafrechtelijke lex certa-beginsel. Anders dan de Hoge Raad zouden wij dan ook de voorkeur geven aan een benadering waarbij in alle gevallen zoveel mogelijk precisie wordt geëist bij de formulering van dwangsomveroordelingen. Dat daarvan in sommige gevallen het gevolg zal zijn dat een eiser zich bij herhaling tot de voorzieningenrechter wendt, moet daarbij op de koop toe worden genomen. Gesteld voor de keuze tussen meer verbodsacties of meer executiegeschillen - of: onevenwichtigheid ten nadele van de eiser of de veroordeelde - zou de bestraffende aard van de dwangsom onzes inziens de doorslag ten gunste van de veroordeelde moeten geven.

In de tweede plaats zijn wij van mening dat het strafkarakter van de dwangsom gevolgen moet hebben, waar een verbod dat met een dwangsom is versterkt materieel overeenkomt met een publiekrechtelijk gesanctioneerd verbod. Is de norm 
die de burgerlijke rechter door middel van een dwangsomveroordeling beoogt te handhaven tevens publiekrechtelijk gesanctioneerd, dan dient de reeds bestaande afschrikkende werking van de publiekrechtelijke sancties meegewogen te worden bij de vaststelling van de dwangsom. Andersom dient de bestuursrechter of de strafrechter, in die gevallen waarin een overtreding van een publiekrechtelijke norm reeds heeft geleid tot verbeurte van privaatrechtelijke dwangsommen, zulks mee te wegen bij het bepalen van de publiekrechtelijke sanctie.

Ten slotte werpen wij de vraag op of het niet de voorkeur verdient om verbeurde dwangsommen te laten toekomen aan de Staat of een ander openbaar fonds. De normovertreding die met de dwangsom wordt gesanctioneerd, heeft een publiek karakter: 'gij zult de rechter gehoorzamen.' Waar het dergelijke publieke rechtsnormen betreft, ligt minder in de rede private partijen financieel voordeel te laten genieten uit handhavingsactiviteiten. 